\title{
Three new species of Patrus Aubé with additional records of Gyrinidae from China (Coleoptera, Gyrinidae)
}

\author{
Zulong LIANG ${ }^{{ }_{1}^{1}}$, Robert B. ANGUS ${ }^{\oplus_{2}}$ \& Fenglong JIA ${ }^{\oplus_{3}, *}$ \\ ${ }^{1,3}$ Institute of Entomology, Life Science School, Sun Yat-sen University, Guangzhou, 510275, \\ Guangdong, China. \\ ${ }^{2}$ Department of Life Sciences (Insects), The Natural History Museum, Cromwell Road, \\ London SW7 5BD, UK. \\ "Corresponding author: 1ssjfl@mail.sysu.edu.cn; fenglongjia@aliyun.com \\ 1Email: liangzl3@mail2.sysu.edu.cn \\ 2Email: R.angus@rhul.ac.uk \\ ${ }^{1} \mathrm{https}: / /$ orcid.org/0000-0002-1289-2697 \\ ${ }^{2} \mathrm{https} / / /$ orcid.org/0000-0002-3860-5617 \\ ${ }^{3} \mathrm{https}: / /$ orcid.org/0000-0003-2391-5038 \\ ${ }^{1}$ urn:1sid:zoobank.org:author:75479591-435D-45B4-9821-234D76B89043
${ }^{2}$ urn:1sid:zoobank.org:author:D14F8A9D-F064-4F67-83AE-70B9384CC880
${ }^{3}$ urn:1sid:zoobank.org:author:AD2EFC37-9653-4965-894A-97317A616A48
}

\begin{abstract}
Three new species of Patrus Aubé, 1838 are described from China: Patrus hainanensis sp. nov. from Hainan; Patrus jiangxiensis sp. nov. from Jiangxi; Patrus shangchuanensis sp. nov. from Guangdong. Eight species/subspecies of Gyrinidae are recorded from China for the first time: Metagyrinus vitalisi (Peschet, 1923), Orectochilus argenteolimbatus Peschet, 1923, Orectochilus murinus Régimbart, 1892, Patrus haemorrhous (Régimbart, 1892), Patrus marginepennis angustilimbus (Ochs, 1925) from Yunnan; Patrus coomani (Peschet, 1925) from Guangdong; Patrus procerus (Régimbart, 1884) from Guangxi; Patrus annandalei (Ochs, 1925) from Hainan. Additional faunistic data of Gyrinidae from China are provided. A key to Chinese species of Patrus Aubé based on examined specimens from China is given.
\end{abstract}

Keywords. Gyrinidae, Patrus, fauna, China, Oriental Region, Palaearctic Region.

Liang Z., Angus R.B. \& Jia F. 2021. Three new species of Patrus Aubé with additional records of Gyrinidae from China (Coleoptera, Gyrinidae). European Journal of Taxonomy 767: 1-39.

https://doi.org/10.5852/ejt.2021.767.1481 


\section{Introduction}

Gyrinidae Latreille, 1810 is the second largest family of aquatic Adephaga Schellenberg, 1806, with a total of approximately 900 species assigned to 13 extant genera (Miller \& Bergsten 2012; Gustafson \& Miller 2017; Miller \& Short 2018), of which seven genera and 56 species/ subspecies have been recorded from China (Mazzoldi 1995, 2003; Hájek \& Fery 2019). Ochs (1929) provided the earliest checklist of Chinese Gyrinidae, which was subsequently cited by Wu (1932). Later on, Cheo (1934) revised the known Gyrinidae from China, with five genera, 31 species included. Since then, several new species were reported from China (Falkenström 1936; Ochs 1936, 1942). Mazzoldi (1995) revised the catalogue of Chinese Gyrinidae, with 46 species/subspecies reported. Since then, four new species of Patrus Aubé, 1838 were described from China (Mazzoldi 1998). Recently, Hájek \& Fery (2019) revised the catalogue of Palaearctic Gyrinidae, with 51 Chinese species/subspecies recorded, including 27 species of Patrus. Despite the studies mentioned above, the taxonomic study of Chinese Gyrinidae is still deficient and in need of a thorough revision.

Patrus is a large gyrinid genus, with about 200 valid species occurring mostly in East, Southeast and South Asia (Miller \& Bergsten 2012). This genus was first established by Aubé (1838) on the basis of the transverse labrum. However, Régimbart (1883) synonymized it with Orectochilus Dejean, 1833 as this character is shared by a considerable number of species of these two genera. Subsequently, Patrus was treated as a subgenus of Orectochilus by Hatch (1925), diagnosed by its lateral pubescence on the pronotum and elytra. This treatment has been widely accepted since. Recently, Patrus was raised to genus level based on phylogenetic results and distinguished from Orectochilus by the six flagellomeres in the antenna and the presence of a pseudofrontal ridge, in addition to the glabrous regions on pronotum and elytra proposed by Hatch (Miller \& Bergsten 2012).

In recent years, we examined a large quantity of material of Gyrinidae from China, among which three species of Patrus new to science and numerous new faunistic records of Gyrinidae were discovered.

\section{Material and methods}

Representative specimens of each species were dissected, and male genitalia were mounted in a drop of glycerol on transparent plastic slides. Photographs of the habitus were taken by using a Zeiss SteREO Discovery V20 microscope or Nikon SM225 microscope, and photographs of the male genitalia were taken by using a Zeiss Axioskop 40 microscope or Zeiss Scope A1 microscope. SEM photographs were taken with a Phenom Prox scanning electronic microscope. All the microscopes mentioned above are located at the Biological Museum of Sun Yat-sen University. Female reproductive tracts were drawn using Adobe Illustrator CC 2014 based on photographs and examination. Anatomical terminology follows Miller \& Bergsten (2012) and Miller et al. (2008)

Distributional information is mainly based on Mazzoldi $(1995,2003)$ and Hájek \& Fery $(2017,2019)$. Only unpublished locality data are listed in this paper. Labels written in Chinese were translated into English and marked with square brackets "[ ]". The taxonomic system used in this study follows Miller \& Bergsten (2012) and Gustafson \& Miller (2017), and morphological terminology largely follows Mazzoldi (1998) and Miller et al. (2008).

\section{Institutional abbreviations}

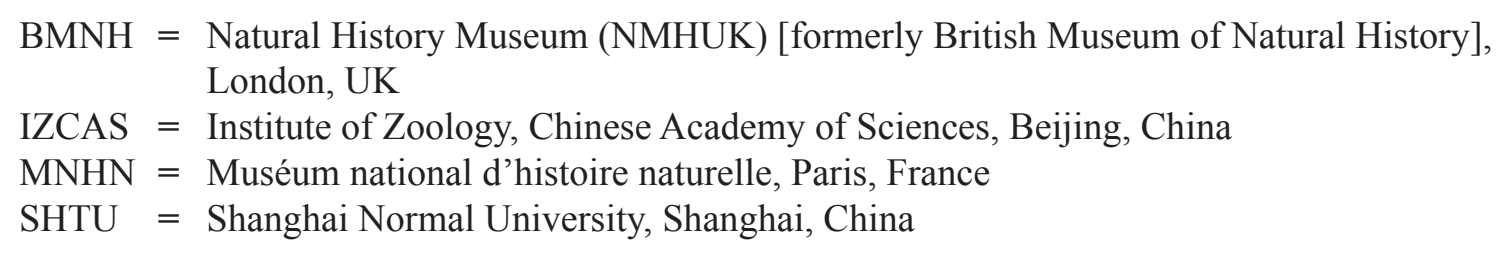


SYSU = Sun Yat-Sen University, Guangzhou, China

In order to compare them with the Chinese material, we checked a male and a female from the type series of Orectochilus murinus Régimbart, 1892 from Sikkim, and other material identified by Régimbart deposited in BMNH. We also checked photographs of a syntype of Patrus haemorrhous (Régimbart, 1891) in MNHN, provided by Antoine Mantilleri.

\section{Results}

\section{Description of new species}

Class Insecta Linnaeus, 1758

Order Coleoptera Linnaeus, 1758

Family Gyrinidae Latreille, 1810

Subfamily Gyrininae Latreille, 1810

Tribe Orectochilini Régimbart, 1882

Genus Patrus Aubé, 1838

Patrus hainanensis sp. nov.

urn:1sid:zoobank.org:act:1001055C-63EB-4EC7-A1E4-92FED32C3A58

Figs $1 \mathrm{~A}-\mathrm{C}, 3,6 \mathrm{~A}$

\section{Diagnosis}

This species can be diagnosed by the following characters combined: 1) labrum less than $1 / 3$ as long as wide, with anterior margin straight; 2) pronotal setose region anteriorly expanded inward onto pronotal disc to middle of dorsal eye; 3) punctation absent on head and pronotum; 4) punctures on surface of elytral glabrous region elongate transverse or oblique, several narrow longitudinal stripes shown on elytral glabrous region, micro-reticulation on elytral glabrous region weak and subtle, very elongate (Fig. 3A, G); 5) in lateral view elytral pubescent area in basal $1 / 2$ distinctly narrower than on pronotum, expanded to similar width apically (Fig. 1C); 6) elytral apex rounded, epipleural angle acute; 7) female elytra similar to those of male; 8) male protarsus as in Fig. 3B-C, adhesive pallet with few adhesive setae and large suction discs, $2 / 3$ length of protibia; 9) aedeagus as in Fig. 3D, median lobe shorter than parameres, extending to $3 / 4$ of their length, strongly laterally expanded in apical $1 / 3 ; 10$ ) female reproductive tract as in Fig. 6A, spermatheca elongate, reniform; fertilization duct broad and flattened, forming several compact hairpin hoops.

This species is a member of Group 2 in Vazirani's (1984) key (Group V in the key of Ochs 1928). The few adhesive setae and large suction discs on the male protarsus and characteristic elytral surface sculpture can easily distinguish this species from other known Chinese species of this group. This species is similar to P. coomani (Peschet, 1925), but can still be easily seperated by its narrow setose region at the elytral base and by the median lobe strongly laterally expanded in apical $1 / 3$.

\section{Etymology}

This species is named after the type locality 'Hainan Province'.

\section{Material examined}

Holotype

CHINA - Hainan • 3 ; 海南尖峰岭五分区 [Hainan, Jianfengling Mt., fifth division]; 8 Jul. 1981; 华立 中采 [Hua Lizhong leg.]; SYSU. 
Paratypes

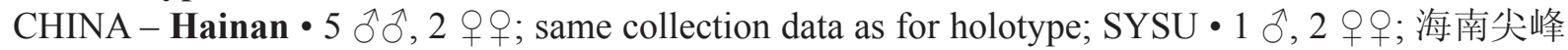
岭五分区 [Hainan, Jianfengling Mt., fifth division,]; 5 Jul. 1981; 张新府采 [Zhang Xinfu leg.]; SYSU -1 J゙; 海南尖峰岭五分区 [Hainan, Jianfengling Mt., fifth division]; 7 Jul. 1981; 黄云采 [Huang Yun leg.]; SYSU ・ 1 ô, 3 o 9 ; 海南尖峰岭五分区 [Hainan, Jianfengling Mt., fifth division]; 7 Jul. 1981; 陈宁美采 [Chen Ningmei leg.]; SYSU ・ 1 ô, 1 q; 海南尖峰岭五分区 [Hainan, Jianfengling Mt., fifth

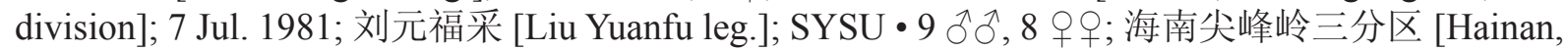
Jianfengling Mt., third division]; 7 Jul. 1981; 李宗申采 [Li Zongran leg.]; SYSU・10 §̂̊, 6 q $q$; 海 南尖峰岭五分区 [Hainan, Jianfengling Mt., fifth division]; 7 Jul. 1981; 梁少营采 [Liang Shaoying leg.]; SYSU • 1 O , 5 우; 海南尖峰岭五分区 [Hainan, Jianfengling Mt., fifth division]; 8 Jul. 1981;

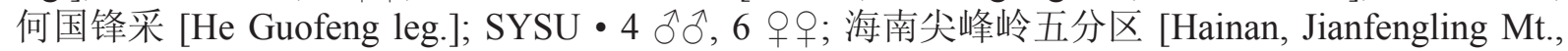
fifth division]; 8 Jul. 1981; 雷群邦采 [Lei Qunbang leg.]; SYSU・1 Ổ; 海南尖峰岭五分区 [Hainan, Jianfengling Mt., fifth division]; 8 Jul. 1981; 李逸昭采 [Li Yizhao leg.]; SYSU ・ 1 中, 海南尖峰岭 五分区 [Hainan, Jianfengling Mt., fifth division]; 8 Jul. 1981; 陈润吉采 [Chen Runji leg.]; SYSU

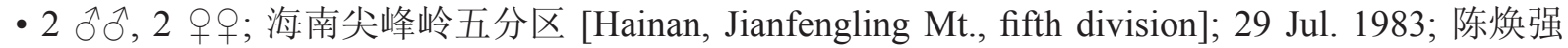
采 [Chen Huanqiang leg.]; SYSU ・ 1 万, 3 o 9 ; 海南尖峰岭五分区 [Hainan, Jianfengling Mt., fifth division]; 29 Jul. 1983; 江世贵采 [Jiang Shigui leg,]; SYSU・1 0 , 3 o o ; 海南尖峰岭五分区 [Hainan, Jianfengling Mt., fifth division]; 8 Sep. 1983; 保护站采 [Reserve station leg.]; SYSU ・ 1 ; ; 海南尖峰 岭天池 [Hainan, Jianfengling Mt., Tianchi]; 8 Sep. 1983; 保护站采 [Reserve station leg]; SYSU.

\section{Description}

MEASUREMEnTs. Holotype: $7.0 \mathrm{~mm}$ in length, $3.0 \mathrm{~mm}$ in width; male: $6.9-9.0 \mathrm{~mm}$ in length, $3.0-3.8 \mathrm{~mm}$ in width; female: $7.0-8.5 \mathrm{~mm}$ in length, $3.2-3.4 \mathrm{~mm}$ in width.

Habitus and colour (Fig. 1A-C). Medium-sized species, oblong-oval in shape, widest just before middle, moderately convex in lateral view. Dorsal side black with strong bronze sheen, stronger on elytron than on head and pronotum. Pronotum and elytra with yellow lateral borders. Ventral side mostly black, with legs and rear of abdomen ferruginous, epipleuron yellow.

HEAD. Labrum wide and short, $1 / 3$ as long as wide, with anterior margin straight; anterior surface smooth; posterior surface with strong punctate-tomentose. Micro-reticulation on surface of clypeus distinct with polygonal meshes. Micro-reticulation on frons and vertex rather distinct, with meshes transverse or oblique (Fig. 3E), gradually obliterated backwards. Punctation absent on head.

Thorax. Pronotum regularly attenuated from base to apex, with margins weakly convex. Surface of pronotal glabrous region with weak and subtle micro-reticulation formed by elongate transverse or oblique meshes (Fig. 3F); punctation absent on pronotum. Lateral pubescence anteriorly expanded inward onto pronotal disc to middle of dorsal eye, posteriorly narrower and parallel to lateral borders. Scutellum wide and short, $1 / 2$ as long as wide, with surface smooth. Lateral pubescence on elytra anteriorly strongly reduced, distinctly narrower than on basal pronotum until middle of elytra, then abruptly expanded and reaching suture just before truncature (Fig. 3A). Pronoto-elytral glabrous region irregular oval, terminating posteriorly with obtuse and wide angle. Surface of elytral glabrous region covered by distinct and rather dense punctation formed by elongate transverse or oblique strioles and with several narrow longitudinal stripes, micro-reticulation invisible under optical microscope, but visible under SEM, similar to that on pronotum (Fig. 3G). Strioles at outer side of elytra much longer than that at inner side. Truncature of elytra straight; epipleural angle almost $90^{\circ}$, acute; sutural angle almost $90^{\circ}$, narrowly rounded. 


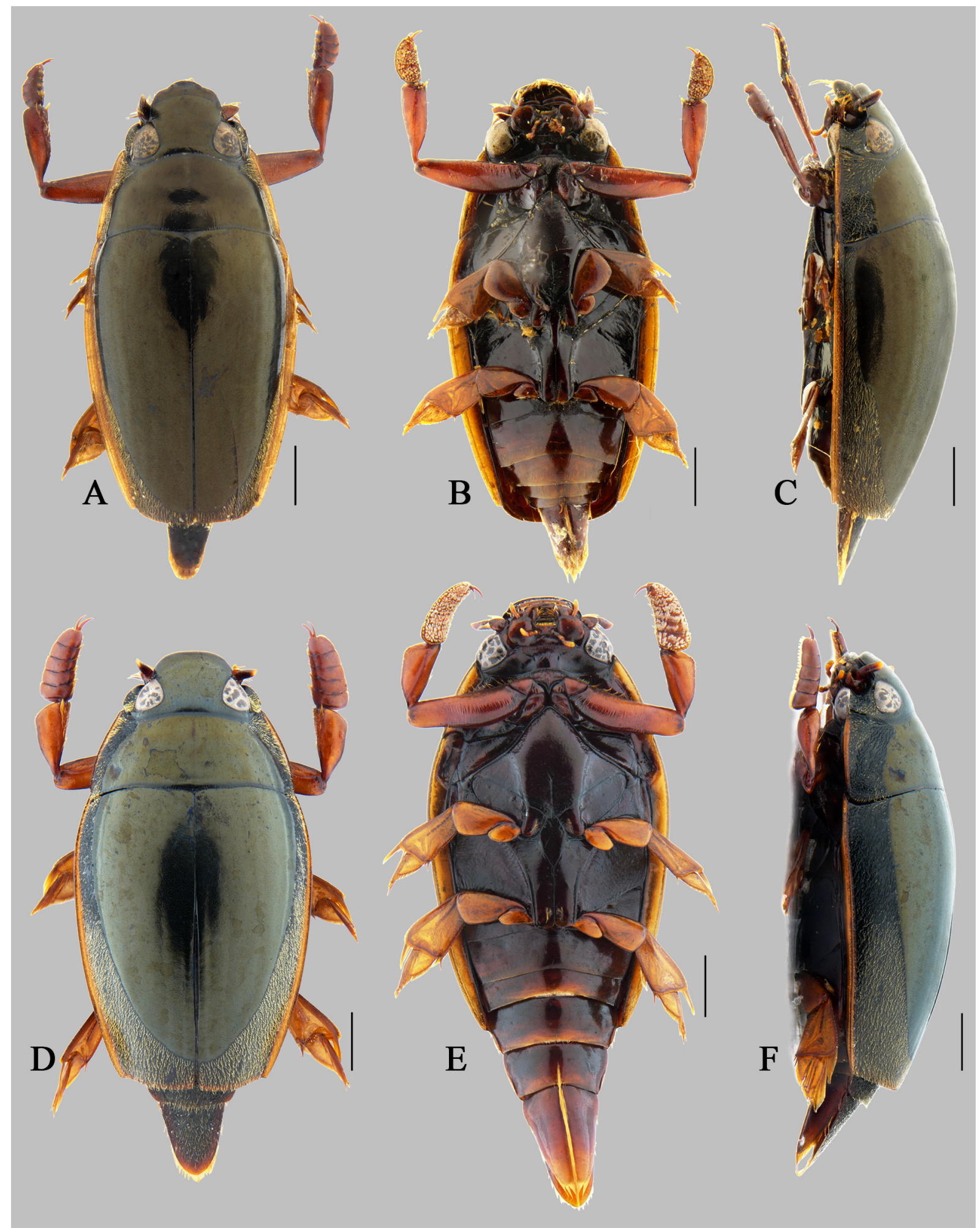

Fig. 1. Habitus. A-C. Patrus hainanensis sp. nov., $\hat{\jmath}$, paratype (SYSU). D-F. Patrus jiangxiensis. sp. nov., $\overbrace{}^{\lambda}$, paratypes (SYSU). A. Dorsal view. B. Ventral view. C. Lateral view. D. Dorsal view. E. Ventral view. F. Lateral view. Scale bars $=1 \mathrm{~mm}$. 


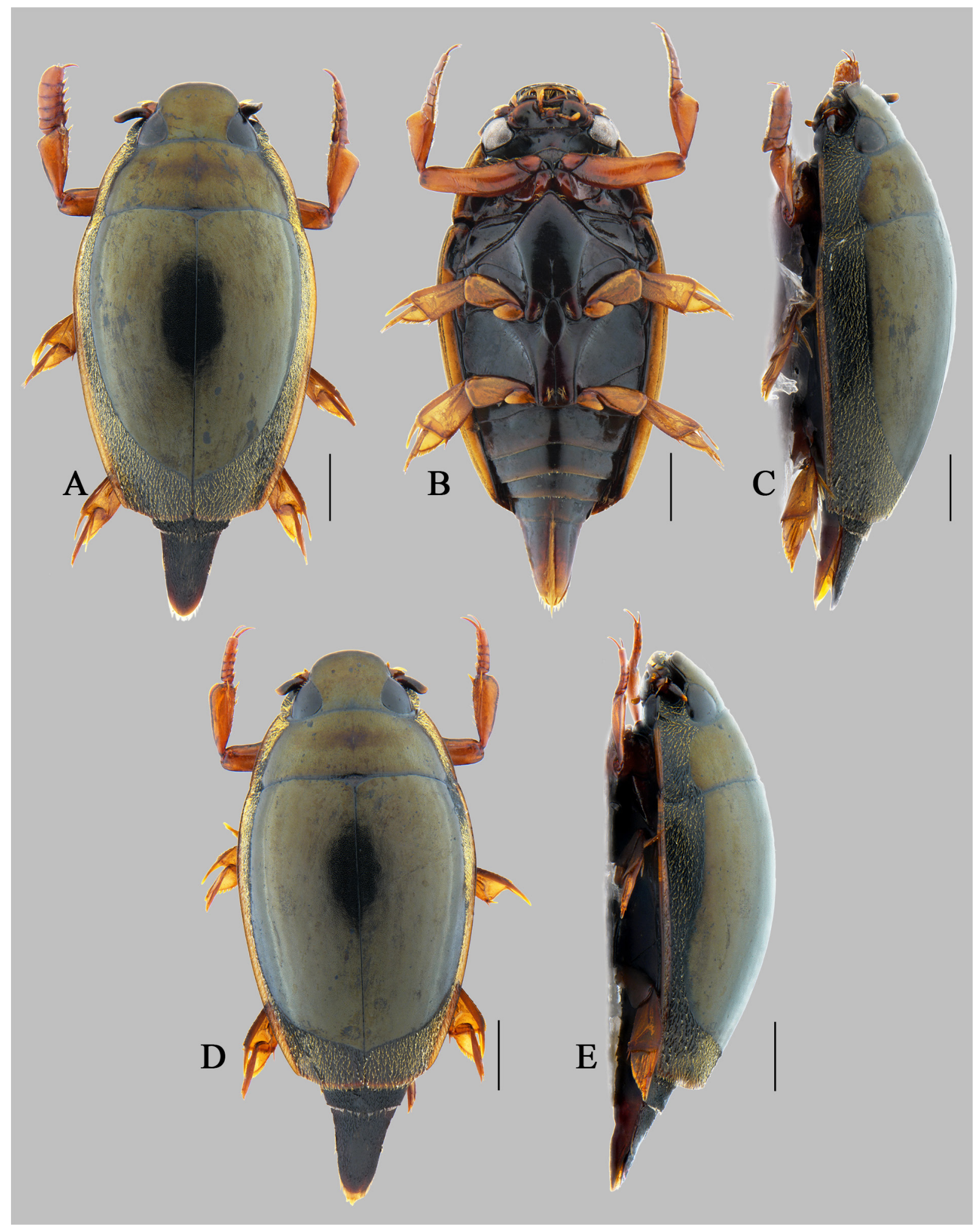

Fig. 2. Habitus of Patrus shangchuanensis sp. nov., paratypes (SYSU). A. $\hat{\jmath}$, dorsal view. B. $\widehat{\partial}$, ventral

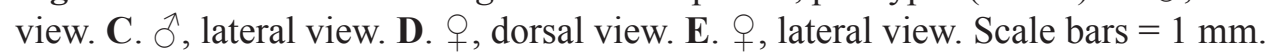


Male Genitalia (Fig. 3D). Median lobe shorter than parameres, extending $3 / 4$ of their length, basal half parallel, strongly laterally expanded in apical $1 / 3$, apical part regularly narrowed toward apex, apex point shortly narrowed.

Female RePRODUCTIVE TRACT (Fig. 6A). Gonocoxosternite elongate, apically narrowly rounded, anterior process elongate; laterotergite elongate, slightly curved apically; vagina elongate; spermatheca elongate, reniform; fertilization duct broad and flattened, forming several compact hairpin hoops; accessory gland short and slender, inserting dorsally on bursa.

SeXual dimorphism. This species exhibits very little sexual dimorphism. Protibia of both sexes rather short and wide, basal third regularly expanded from base to apex, apical two-thirds subparallel, anteroexternal angle rather obliterated. Protarsus in male expanded, sub-oval, slightly more than $1 / 2$ as long as protibia, slightly wider (Fig. 3B), inner margin straight, external margin convex, ventral side with large sucking disc on top of adhesive setae (Fig. 3C), while not expanded and without adhesive setae in female.

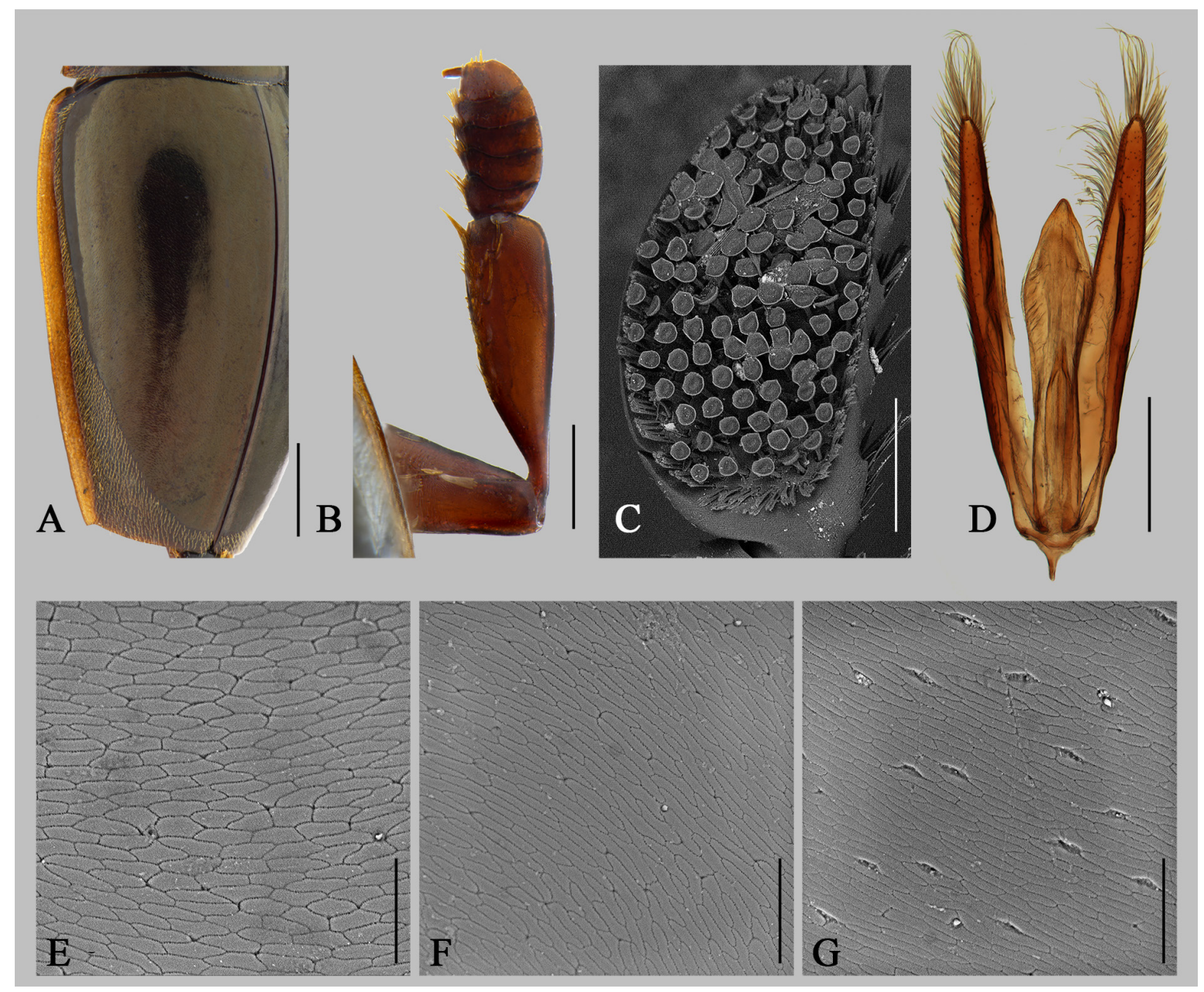

Fig. 3. Patrus hainanensis sp. nov., §ิ (SYSU). A. Left elytron, paratype. B. Front leg., paratype C. Front tarsus, paratype. D. Genitalia, holotype. E. Surface sculpture on head, paratype. F. Surface sculpture on pronotum, paratype. G. Surface sculpture on elytra, paratype. Scale bars: A $=1 \mathrm{~mm}$; B, D $=0.5 \mathrm{~mm}$; C $=200 \mu \mathrm{m} ; \mathrm{E}-\mathrm{G}=30 \mu \mathrm{m}$. 


\section{Distribution}

Only known from type locality Jianfengling Mt, Hainan Province, China.

\section{Patrus jiangxiensis sp. nov.}

urn:1sid:zoobank.org:act:74887BE8-29AD-43F6-8E93-84770844D59C

Figs 1D-F, 4, 6B

\section{Diagnosis}

This species can be diagnosed by the following characters combined: 1) labrum less than $1 / 3$ as long as wide, with anterior margin straight; 2) pronotal setose region anteriorly expanded inward onto pronotal disc to external third of dorsal eye; 3 ) dorsal surface with strong and dense micro-punctation, much stronger on elytron (Fig. 4E-G); 4) pronoto-elytral glabrous region regular oval, terminating posteriorly with an obtuse but not very wide angle, slightly wider in female (Fig. 4A); 5) elytral apex straight, epipleural angle obtuse; 6) male protarsus as in Fig. 4B-C, adhesive pallet with dense adhesive setae and

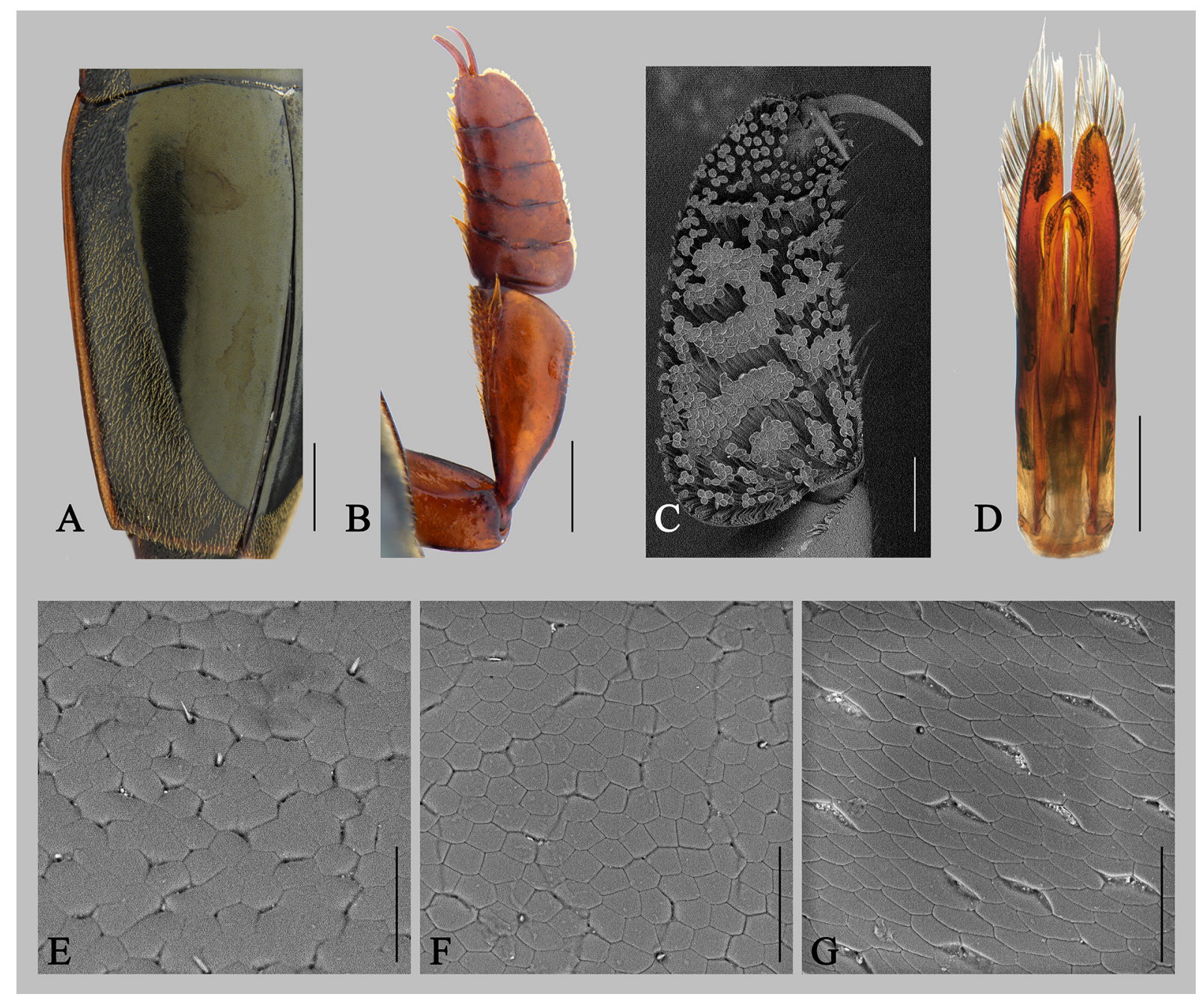

Fig. 4. Patrus jiangxiensis sp. nov., $\widehat{\jmath}$ (SYSU). A. Left elytron, paratype. B. Front leg, paratype. C. Front tarsus, paratype. D. Genitalia, holotype. E. Surface sculpture on head, paratype. F. Surface sculpture on pronotum, paratype. G. Surface sculpture on elytra, paratype. Scale bars: A $=1 \mathrm{~mm} ; \mathrm{B}, \mathrm{D}=0.5 \mathrm{~mm}$; $\mathrm{C}=200 \mu \mathrm{m} ; \mathrm{E}-\mathrm{G}=30 \mu \mathrm{m}$. 
small suction discs, distinctly longer than protibia; 7) aedeagus as in Fig. 4D, median lobe broad, shorter than parameres, extending $4 / 5$ of their length; 10) female reproductive tract as in Fig. 6B, spermatheca elongate, $\mathrm{C}$-shaped; fertilization duct slender, forming several loose hairpin hoops.

This species is also a member of Group 2 in Vazirani's (1984) key. It can be further assigned to the wuisubgroup proposed by Mazzoldi (1998) by the very large protarsus in the male. This species closely resembles Patrus wangi (Mazzoldi, 1998) described from Zhejiang and Anhui. These two species both have a well-developed protarsus which is distinctly longer than the protibia. However, it can be easily distinguished from the latter by the shape of the protarsus in the male (Fig. 4B) and of the elytral glabrous region in the female. Besides, it is larger in size, the truncature of the protibia is more oblique and the median lobe of the aedeagus lacks the hook-like process (Fig. 4D).

The new species is also similar to $P$. wui (Ochs, 1932). Compared to $P$. wui, this species is larger in size, the protarsus is also larger, longer than the protibia, the glabrous region is less broad posteriorly, and the median lobe of the aedeagus is broader.

\section{Etymology}

This species is named after the type locality 'Jiangxi Province'.

\section{Material examined}

\section{Holotype}

CHINA - Jiangxi - ô; Jiangxi Prov. Pingxiang City, Luxi County, Wugongshan; 2747'53" N, $114^{\circ} 14^{\prime} 83^{\prime \prime}$ E; alt. 520 m; 22-24 Sep. 2016; Ruijuan Zhang and Yudan Tang leg.; SYSU.

\section{Paratypes}

CHINA - Jiangxi • 30 ex.; same collection data as for holotype; SYSU • 2 q $q$; Jiangxi Prov. Shangyou

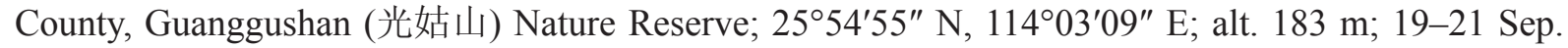
2016; Ruijuan Zhang and Yudan Tang leg.; SYSU • 14 ex.; 江西靖安县观音岩 [Guanyinyan, Jiangxi]; 29.04 N, 115.14 E; alt. 690 m; 20 Jul. 2014; 林仁超采 [Lin Renchao leg.]; SYSU • 1 ㅇ ; 江西靖安县 三爪仑乡白水洞景区 [Jiangxi, Jing'an, Sanzhualun, Baishuidong Scenic Area]; 29.04 N, 115.11 E; alt. 660 m; 22 Jul. 2014; 林仁超采 [Lin Renchao leg.]; SYSU ・ 1 ぶ; 江西井冈山白银湖 [Jiangxi, Jinggangshan, Baiyinhu]; alt. 880 m; 23 Apr. 2011; 采集人: 赵爽 [Zhao Shuang leg.]; SYSU・ 1 on, 3 우 ; 江西井冈山湖羊塔 [Jiangxi, Jinggangshan, Huyangta]; 28 Apr. 2011; 采集人: 贾风龙 [Jia Fenglong leg.]; SYSU ・ 1 万; 江西井冈山 [Jiangxi, Jinggang Shan]; 1 Apr. 2011; 李韵采 [Li Yun

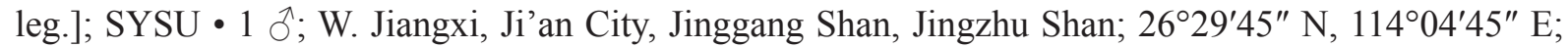
alt. 1130 m; 2 Aug. 2014; Chen, Hu, Lv and Yu leg.; in the stream; SHNU.

\section{Description}

Measurements. Holotype: $8.5 \mathrm{~mm}$ in length, $3.9 \mathrm{~mm}$ in width; male: $8.4-9.8 \mathrm{~mm}$ in length, $3.9-4.0 \mathrm{~mm}$ in width; female: $7.0-8.6 \mathrm{~mm}$ in length, $3.1-3.9 \mathrm{~mm}$ in width.

Habitus and colour (Fig. 1D-F). Medium-sized species, oblong-oval in shape, widest just before middle, moderately convex in lateral view. Dorsal side black with strong bronze sheen. Pronotum and elytra with yellow lateral borders. Ventral side mostly reddish brown to dark brown, with legs and epipleura yellow to reddish yellow, last abdomen ferruginous.

HEAD. Labrum wide and short, $1 / 3$ as long as wide, with anterior margin straight; anterior surface smooth; posterior surface with strong punctate-tomentose. Clypeus slightly shorter than labrum, with anterior margin straight. Fronto-clypeal suture distinct. Surface of clypeus with weak micro-reticulation anteriorly, while distinct posteriorly, among meshes of micro-reticulation with dense irregular punctation. Surface 
on frons and vertex with strong micro-reticulation formed by isodiametric polygonal meshes, gradually obliterated backwards. Amongst meshes of the micro-reticulation strong irregular-shaped punctation (Fig. 4E).

Thorax. Pronotum regularly attenuated from base to apex, with margins weakly convex. Surface of pronotal glabrous region with distinct micro-reticulation formed by isodiametric polygonal meshes and strong irregular punctation (Fig. 4F), much of which merges in rows to form distinct wrinkles. Lateral pubescence anteriorly expanded inward onto pronotal disc to external third of eye, posteriorly weakly reduced backwards in concave line. Scutellum wide and short, less than $1 / 2$ as long as wide, with surface smooth. Pronoto-elytral glabrous region regular oval, terminating posteriorly with obtuse but not very wide angle (Fig. 4A). Lateral pubescent band in male anteriorly as wide as pronotal one, subparallel to elytral margin backwards until middle of elytron, then regularly expanded, reaching suture at about onetenth of distance from truncature; in female anteriorly as wide as pronotal one, parallel to elytral margin backwards until $2 / 3$ of elytron, then regularly expanded, reaching suture at about $1 / 12$ of distance from truncature, so that elytral glabrous region in female slightly wider. Surface of elytral glabrous region covered by weak micro-reticulation formed by transverse or oblique and slightly elongate polygonal meshes and by strong punctation formed by short transverse or oblique strioles (Fig. 4G). Truncature of elytra straight; epipleural angle obtuse, narrowly rounded, sutural angle almost $90^{\circ}$, narrowly rounded.

Male genitalia (Fig. 4D). Median lobe shorter than parameres extending $4 / 5$ of their length, basal third parallel, then slightly narrowed until apical third, sub-apex parallel, apical part regularly narrowed, apex point shortly narrowed.

FeMALE REPRODUCTIVE TRACT (Fig. 6B). Gonocoxosternite elongate, apically narrowly protruding, anterior process short; laterotergite elongate, slightly narrowed towards apex; vagina elongate; spermatheca elongate, C-shaped, strongly curved; fertilization duct slender, forming several loose hairpin hoops; accessory gland short and slender, inserting dorsally on bursa.

Sexual dimorphism. Male slightly larger in size than female; protibia in male short and wide, short triangular, strongly expanded exteriorly towards apex, apex of protibia obliquely truncate, anteroexternal angle obtuse, rounded (Fig. 4B), while shorter and less expanded, and apex straight-truncate in female. Protarsus of male large, strongly expanded, distinctly longer than protibia, slightly narrowed towards apex, ventral side with dense adhesive setae and small suction discs (Fig. 4C); elytral glabrous region slightly broader posteriorly in female.

\section{Distribution}

Known from Pingxiang, Shangyou, Jingxi and Jinggangshan in Jiangxi Province, China.

Patrus shangchuanensis sp. nov. urn:1sid:zoobank.org:act:6EE82957-25AB-4EE0-90AC-3F5250BCD0B9

Figs 2, 5, 6C

\section{Diagnosis}

This species can be diagnosed by the following characters combined: 1) labrum less than $1 / 3$ as long as wide, with anterior margin straight; 2) pronotal setose region anteriorly expanded inward onto pronotal disc to external third of dorsal eye; 3 ) dorsal surface with strong and dense micro-punctation, much stronger on elytron (Fig. $5 \mathrm{~F}-\mathrm{H})$; 4) pronoto-elytral glabrous region regularly oval in male, terminating posteriorly with obtuse but not very wide angle, with two postero-lateral expansions in females (Fig. 5AB); 5) elytral apex straight, epipleural angle obtuse; 6) male protarsus as in Fig. 5C-D, adhesive pallet 
with dense adhesive setae and small suction discs, almost as long as protibia; 7) aedeagus as in Fig. 5E, median lobe shorter than parameres, extending $4 / 5$ length, apical part notably narrowed, sub-apically slightly constricted; 10) female reproductive tract as in Fig. 6C, spermatheca elongate, C-shaped; fertilization duct rather slender and flattened, forming several loose hairpin hoops.

This species is also a member of the wui-subgroup. It closely resembles Patrus wangi (Mazzoldi, 1998) and P. wui (Ochs, 1932). All these three species show a distinct sexual dimorphism in the shape of the elytral glabrous region. Two postero-lateral expansions are shown in female of both, the new species and $P$. wangi but much weaker in this species than in $P$. wangi so that the lateral pubescence on the elytra is visible from above throughout (Figs 2D, 5B). Besides, the protarsus in the male is less developed, at most as long as protibia in this species (Fig. 5C-D). The elytral glabrous region in the female is much broader posteriorly than in male $P$. wui, whereas postero-lateral expansions are not present in this species. The male genitalia of these three species are also distinctly different from each other.

\section{Etymology}

This species is named after the type locality 'Shangchuan Island'.

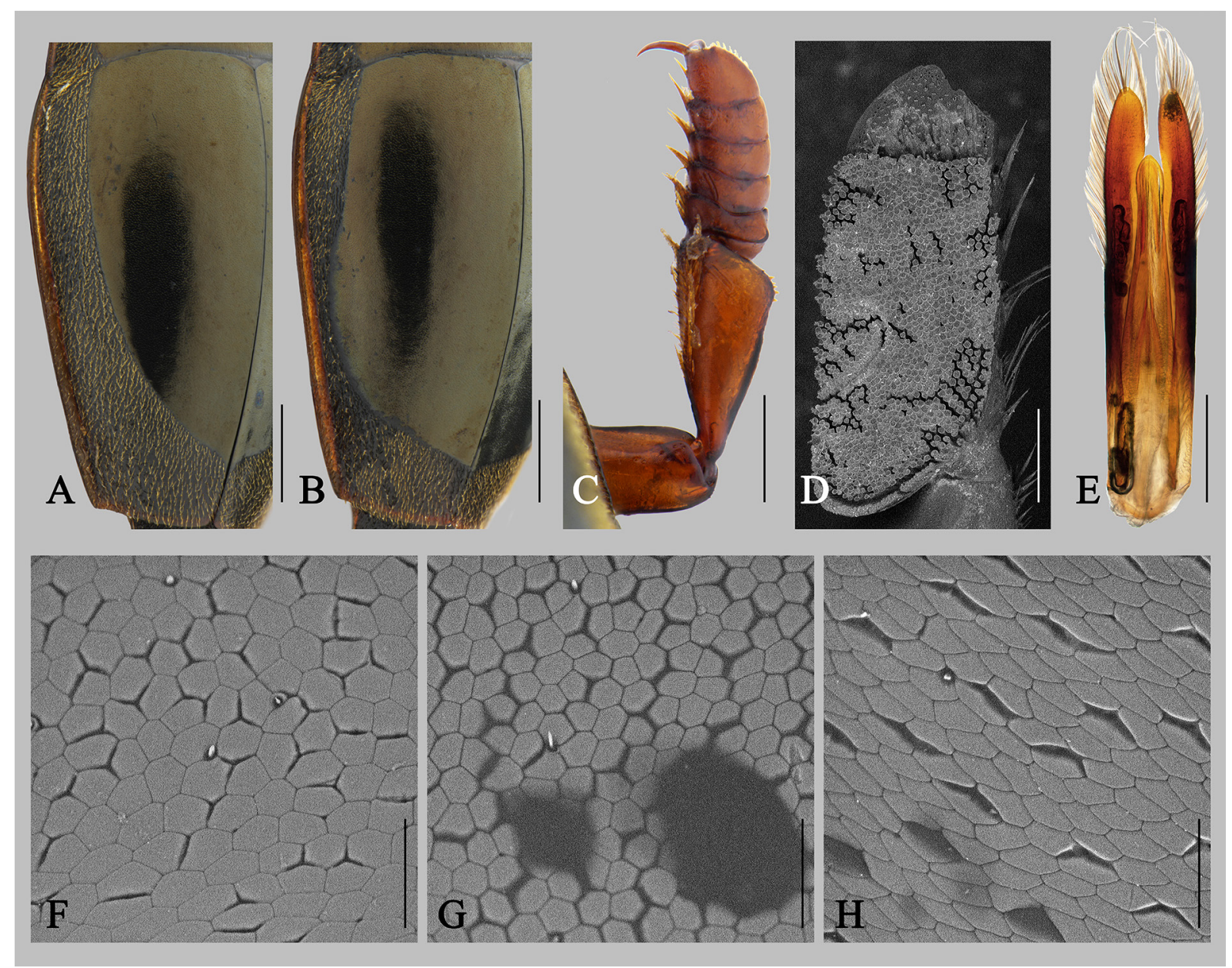

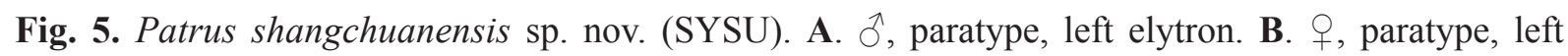
elytron. C. $\widehat{\partial}$, paratype, front leg. D. $\widehat{\partial}$, paratype, front tarsus. E. $\widehat{\jmath}$, holotype, genitalia. F. $\hat{\partial}$, paratype,

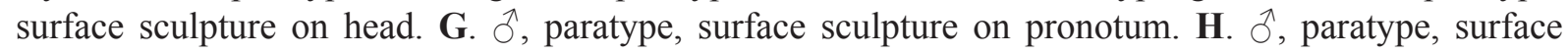
sculpture on elytra. Scale bars: A-B $=1 \mathrm{~mm} ; \mathrm{C}, \mathrm{E}=0.5 \mathrm{~mm} ; \mathrm{D}=200 \mu \mathrm{m} ; \mathrm{F}-\mathrm{H}=30 \mu \mathrm{m}$. 


\section{Material examined}

\section{Holotype}

CHINA - Guangdong - O ; 广东省台山市上川岛猕猴省级自然保护区 [Guangdong, Taishan City,

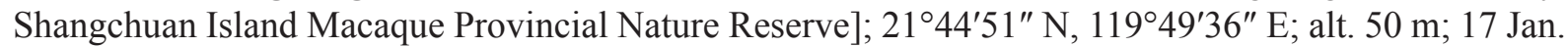
2019; 贾凤龙, 梁祖龙采 [Jia Fenglong and Liang Zulong leg.]; SYSU.

\section{Paratypes}

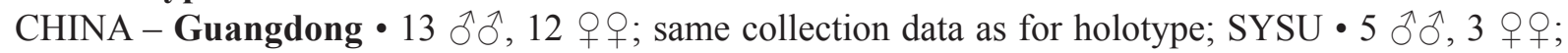
广东省台山市上川岛猕猴省级自然保护区 [Guangdong, Taishan City, Shangchuan Island Macaque

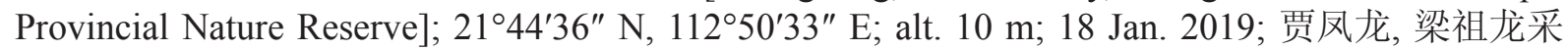
[Jia Fenglong and Liang Zulong leg.]; SYSU・1 万; 广东省台山市上川岛猕猴省级自然保护区石 背潭 [Guangdong, Taishan City, Shangchuan Island Macaque Provincial Nature Reserve, Shibeitang]; $21^{\circ} 46^{\prime} 1^{\prime \prime}$ N, 112 $49^{\prime} 2^{\prime \prime}$ E; alt. 20 m; 19 Jan. 2019; 贾凤龙, 梁祖龙采 [Jia Fenglong and Liang Zulong leg.]; SYSU.

\section{Description}

Measurements. Holotype: $7.7 \mathrm{~mm}$ in length, $3.6 \mathrm{~mm}$ in width; male: $7.1-8.6 \mathrm{~mm}$ in length, 3.2-3.6 mm in width; female: $6.9-7.6 \mathrm{~mm}$ in length, $2.9-3.4 \mathrm{~mm}$ in width.

Habitus and colour (Fig. 2A-E). Medium-sized species, oval in shape, widest just before middle, moderately convex in lateral view. Dorsal side black with strong bronze sheen. Pronotum and elytra with yellow lateral borders. Ventral side mostly black, with legs and epipleura yellow to reddish yellow.
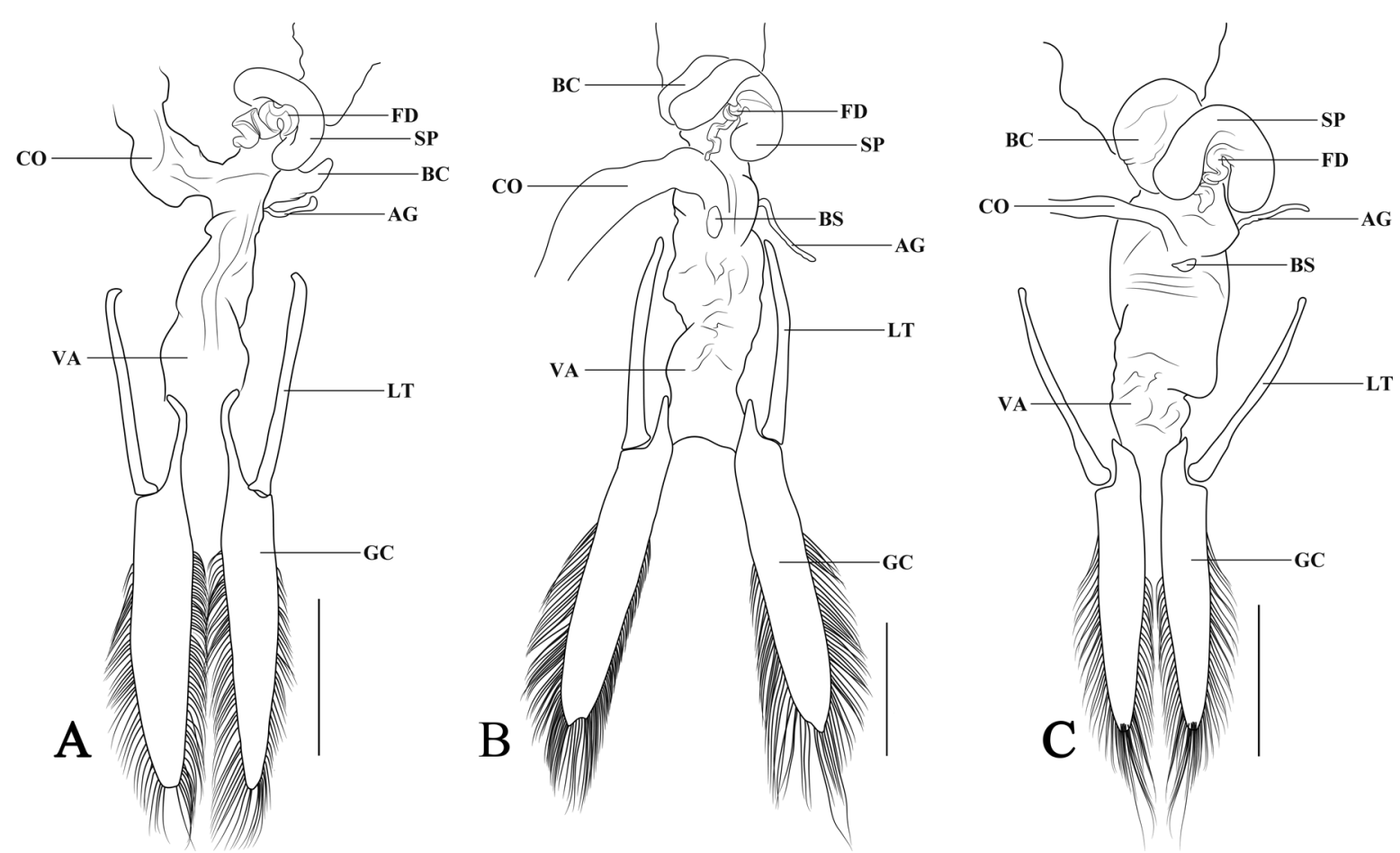

Fig. 6. Female reproductive tract of new species, paratype with the same collection data as for holotype (SYSU). A. Patrus hainanensis sp. nov. B. Patrus jiangxiensis sp. nov. C. Patrus shangchuanensis sp. nov. Abbreviations: $\mathrm{AG}=$ accessory gland; $\mathrm{BC}=$ bursa copulatrix; $\mathrm{BS}=$ bursa sclerite; $\mathrm{CO}=$ common oviduct; $\mathrm{FD}=$ fertilization duct; $\mathrm{GC}=$ gonocoxa; $\mathrm{LT}=$ laterogtergite; $\mathrm{SP}=$ spermatheca; $\mathrm{VA}=$ vagina. Scale bars $=500 \mu \mathrm{m}$. 
LIANG Z. et al., Three new species of Patrus with additional records of Gyrinidae from China

HeAD. Labrum wide and short, slightly less than $1 / 3$ as long as wide, with anterior margin straight; anterior surface smooth; posterior surface strongly punctate-tomentose. Clypeus slightly shorter than labrum, with anterior margin slightly concave. Fronto-clypeal suture distinct. Surface of clypeus with strong micro-reticulation formed by isodiametric polygonal meshes, among meshes with strong and dense punctation. Surface of frons and vertex with strong micro-reticulation formed by isodiametric polygonal meshes, gradually obliterated backwards. Amongst meshes of micro-reticulation strong irregular-shaped punctation (Fig. 5F).

Thorax. Pronotum regularly attenuated from base to apex, with margins weakly convex. Surface of pronotal glabrous region with strong irregular-shaped punctation, some of which merges in rows to form distinct wrinkles (Fig. 5G), micro-reticulation on median disc strong, formed by isodiametric polygonal meshes, obliterated towards margins. Lateral pubescence anteriorly expanded inward onto pronotal disc to external third of dorsal eye, posteriorly weakly reduced backwards in concave line. Scutellum wide and short, less than $1 / 2$ as long as wide, with surface smooth. Pronoto-elytral glabrous region in male regularly oval. Lateral pubescent area in male anteriorly as wide as on pronotum, parallel to elytral margin backwards until the middle of elytron, then regularly expanded, reaching suture at about $1 / 8$ to truncature (Fig. 5A). Pronoto-elytral glabrous region in female in characteristic shape, with weak postero-lateral expansion at each side (Fig. 5B). Lateral pubescence in female anteriorly two-fifths slightly narrowed backwards, then regularly narrowed in concave line, apical fifth suddenly expanded, reaching suture at same position as in male. Surface of elytral glabrous region covered by distinct micro-reticulation formed by transverse or oblique and slightly elongate polygonal meshes and by strong punctation formed by short transverse or oblique strioles (Fig. $5 \mathrm{H}$ ). Truncature of elytra straight; epipleural angle obtuse, narrowly rounded, sutural angle almost right angle, narrowly rounded.

Front Legs. Protibia in male short and wide, short triangular, strongly expanded exteriorly towards apex, apex of protibia obliquely truncate, antero-external angle obtuse, narrowly rounded (Fig. 5C). Protibia in female slenderer than in male. Protarsus of male large, strongly expanded, almost as long as protibia, basal four-fifths subparallel, apical fifth regularly narrowed (Fig. 5D).

Male GEnitalia (Fig. 5E). Median lobe notably shorter than parameres, basal third parallel, then slightly narrowed backwards until apical third, slightly expanded subapically, apical part regularly narrowed, apex form obtuse angle.

Female ReProductive tRACt (Fig. 6C). Gonocoxosternite elongate, apically narrowed, anterior process short and broad; laterotergite elongate, slightly narrowed towards apex; vagina elongate; bursa rather broad; spermatheca elongate, C-shaped, strongly curved; fertilization duct rather slender and flattened, forming several loose hairpin hoops; accessory gland short and slender, inserting dorsally on bursa.

SeXUal DIMORPhism. Protibia in male short and wide, short triangular, strongly expanded exteriorly towards apex, apex of protibia obliquely truncate, antero-external angle obtuse, narrowly rounded (Fig. 5C), while slender and less expanded, and apex straight-truncate in female. Protarsus of male large, strongly expanded, almost as long as protibia, basal four-fifths subparallel, apical fifth regularly narrowed, ventral side with dense adhesive setae and small suction disks (Fig. 5D); elytral glabrous region regularly oval in male and with two weak postero-lateral expansion in female.

\section{Distribution}

Only known from the type locality Shangchuan Island, Guangdong Province, China. 


\title{
New faunistic records of Gyrinidae
}

\author{
Subfamily Gyrininae Latreille, 1810 \\ Tribe Dineutini Desmarest, 1851 \\ Genus Dineutus Macleay, 1825
}

Dineutus australis (Fabricius, 1775)

Gyrinus australis Fabricius, 1775: 235.

Gyrinus rufipes Fabricius, 1801: 276.

Gyrinus dentipennis Macleay, 1825: 30.

Gyrinus limbatus Macleay, 1825: 30.

Gyrinus iridis Hope, 1842: 48.

Dineutus dentatus Suffrian, 1842: 256.

Dineutes janthinus Blanchard, 1843: pl. 4.

Dineutus leucopoda Montrouzier, 1860: 245.

\section{Material examined}

CHINA - Hainan • 2 q ; 广东海南 [Guangdong Hainan]; 5 Jun. 1957; 赵养昌采 [Zhao Yangchang leg.]; SYSU • 2 9 9 ; 海南岛尖峰岭 [Hainan Is., Jianfengling Mt.]; 19 Dec. 1963; 彭统序采 [Peng Tongxu leg.]; SYSU • 2 ex.; 广东海南三亚 [Guangdong, Hainan, Sanya]; alt. 10 m; 5 Apr. 1960; 采集 者: 李学忠 [Li Xuezhong leg.]; IZCAS. - Jiangxi ・ 1 J ; 江西南昌 [Jiangxi, Nanchang]; Jul. 1963; 马 恩沛采 [Ma Enpei leg.]; SYSU.

\section{Distribution}

Distributed in the Oriental and Australian Regions, known from Fujian, Guangdong, Guangxi, Hong Kong, Taiwan in China. New for Hainan and Jiangxi.

Dineutus mellyi (Régimbart, 1882)

Dineutes mellyi Régimbart, 1882: 399.

Dineutes sauteri Uyttenboogaart, 1915: 140.

\section{Material examined}

CHINA - Henan・1 + ; 河南信阳鸡公山 [Henan, Xinyang, Jigongshan Mt.]; Aug. 1936; SYSU.

\section{Distribution}

Known from China (Fujian, Guangdong, Guangxi, Guizhou, Hong Kong, Hubei, Hunan, Jiangxi, Shandong, Sichuan, Taiwan, Xizang, Yunnan, Zhejiang), Japan and Vietnam. New for Henan.

\section{Dineutus orientalis (Modeer, 1776)}

Gyrinus orientalis Modeer, 1776: 160.

Dineutes marginatus Sharp, 1873: 56.

Dineutes quadrispina Fairmaire, 1878: 88.

\section{Material examined}

CHINA - Beijing • 1 ex.; 北京白石桥 [Beijing, Baishiqiao]; 5 Apr. 1955; 张毅然采 [Zhang Yiran leg.]; IZCAS. - Hainan • 11 ex.; Hainan Is. S China, Ka-chek, K'ieng-tong District; 4 May 1932; F.K. To leg.; SYSU 1 O ; 海南 [Hainan]; 16 Jul. 1957; 利翠英采 [Li Cuiying leg.]; SYSU • 1 ex.; Hainan, Fanyang; 
15 Apr. 1936; G. Ros leg.; IZCAS. - Shaanxi • 4 ex.; 陕西西安浐灞 [Shaanxi, Xi’an, Chanba]; 21 May 2010; 许升金采 [Xu Shengjin leg.]; SYSU. - Tianjin • 2 ex.; 天津八里台 [Tianjin, Balitai]; 1 May 1955; 刘英采 [Liu Ying leg.]; SYSU.

\section{Distribution}

Distributed in China (Fujian, Guangdong, Guangxi, Guizhou, Hebei, Hong Kong, Hubei, Jiangsu, Liaoning, Shandong, Shanghai, Sichuan, Taiwan, Xizang, Yunnan, Zhejiang), Japan, Korea, Vietnam and Laos. New for Beijing, Hainan, Shaanxi and Tianjin.

Genus Porrorhynchus Laporte, 1835

Porrorhynchus landaisi Régimbart, 1892

Porrhorrhynchus landaisi Régimbart, 1892: 667.

Porrhorrhynchus barthelemyi Régimbart, 1902: 5.

Dineutus (Porrorhynchus) landaisi latilimbus Ochs, 1926: 193.

\section{Material examined}

CHINA - Guangxi ・5 ふぇ, 3 우; 广西百寿 [Guangxi, Baishou]; 27 Jul. 1952; IZCAS.

\section{Distribution}

Known from southern China (Guizhou, Hainan, Yunnan and Xizang) and northern Vietnam. New for Guangxi.

Tribe Gyrinini Latreille, 1810

Genus Gyrinus Geoffroy, 1762

Gyrinus convexiusculus Macleay, 1871

Gyrinus convexiusculus Macleay, 1871: 128.

Gyrinus huttoni Pascoe, 1877: 141.

Gyrinus simoni Régimbart, 1883: 163.

\section{Material examined}

CHINA - Yunnan - 5 ex. 云南西双版纳预阿 [Yunnan, Xishuangbanna, Meng'e]; 1050-1080 m; 1958.VIII.22; 采集人: 王书永 [leg. Wang Shuyong]; IZCAS・ 5 ex.; 云南西双版纳预遮 [Yunnan, Xishuangbanna, Mengzhe]; alt. 1200 m; 8 Apr. 1958; 采集人: 王书永 [Wang Shuyong leg.]; IZCAS

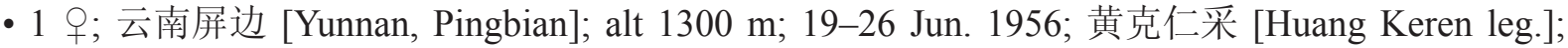
IZCAS • 8 ex.; 云南思茅附近 [Yunnan, near Simao]; 26 Mar. 1957; A. 孟恰茨基采 [Менчацкий leg.]; IZCAS.

\section{Distribution}

Widely distributed in the Oriental and Australian Regions, known from Jiangxi, Taiwan and Xizang. New for Yunnan.

\section{Gyrinus curtus Motschulsky, 1866}

Gyrinus curtus Motschulsky, 1866: 165.

Gyrinus fulvescens Takizawa, 1931: 17. 


\section{Material examined}

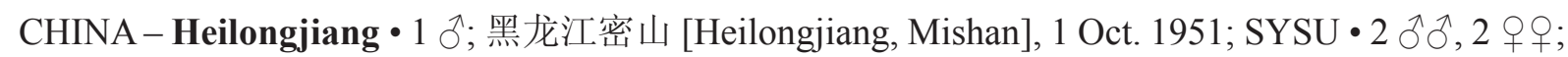
Heilongjiang Prov., Yichun, Wuying, Wuying National Forest Park; 11 Jul. 2004; Li-Zhen Li leg; SHNU.

\section{Distribution}

Narrowly distributed in China (Beijing and Liaoning) and Japan. New for Heilongjiang.

Gyrinus mauricei Fery \& Hájek, 2016

Gyrinus mauricei Fery \& Hájek, 2016: 651.

Gyrinus orientalis Régimbart, 1883: 167.

\section{Material examined.}

CHINA - Guangxi • 11 ex.; 广西临桂黄沙 [Guangxi, Lingui, Huangsha]; 13 Aug. 2006; 黄国华采 [Huang Guohua leg.]; SYSU • 1 đ’; 广西容县 [Guangxi, Rongxian]; 10 Oct. 1962; 古德祥采 [Gu Dexiang leg.]; SYSU • 6 ex.; Guangxi Prov., Jiuwangdashan, Yangmeiao; 2511'42" N, 108 38'51" E; alt. 1183 m; 20 Jul. 2015; Rencao Lin and Yudan Tang leg.; SYSU. - Hubei ・ 1 ○; 湖北英山吴家山 [Hubei, Yingshan County, Wujiashan Mout.]; alt. 800-1000 m; 12 Jul. 2006; 采集人: 石否 [Shi Lei leg.]; SYSU. - Hunan - 1 \% 湖南古丈县高望界国家自然保护区 [Hunan, Guzhang County, Gaowangjie National Reserve]; $28^{\circ} 39.898^{\prime}$ N, 110³.575' E; 1053 m; 21 Jun. 2017; F.-L. Jia leg.; SYSU. - Zhejiang

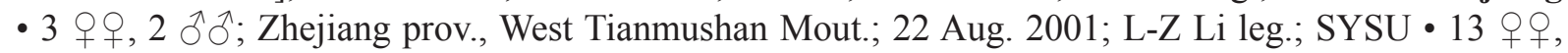

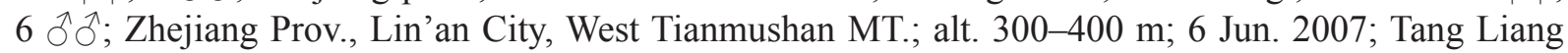
leg.; SHNU.

\section{Distribution}

Known from China (Fujian, Guangdong, Guizhou, Hong Kong, Jiangsu, Jiangxi, Shanghai, Sichuan, Yunnan), Russia (Far East) and Vietnam. New for Guangxi, Hubei, Hunan and Zhejiang.

\section{Gyrinus minutus Fabricius, 1798}

Gyrinus minutus Fabricius, 1798: 65.

Gyrinus kirbii Marsham, 1802: 100.

Gyrinus ohbayashii Satô, 1985: 51.

\section{Material examined}

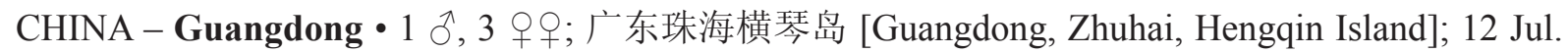
2005; 贾奥采 [Jia Yue leg.]; SYSU. - Inner Mongolia • 4 우; China, Nei Mongol, Hulunbeier, Huihe; 25 Jul. 2013; Shi Li, Jin Chunyun and De chaoqun leg.; SYSU • 2 ภ̊, 5 웅 中国内蒙古呼伦贝尔 中蒙边境国门外 [China, Inner Mongolia, Hulunbeier, near the border of China and Mongolia]; 29 Aug. 2014; 贾风龙采 [Fenglong Jia leg.]; SYSU • 1 q; Inner Mongolia, Hanma Management Centre, a stream by monitoring station; 30 Jul. 2014; Shi Li, Zhu Lixuan, Gao Xuefeng and Chen chao leg.; SYSU ・ 1 平; 内蒙古海拉尔市 [Inner Mongolia, Hailaer City]; 23-26 Jul. 2003; 采集人: 贾凤龙 [Jia Fenglong leg.]; SYSU.

\section{Distribution}

Widely distributed in the Palaearctic Region. Known from Heilongjiang, Jilin, Liaoning, Xinjiang in China. New for Guangdong and Inner Mongolia. 


\section{Remarks}

As it is a typical northern species, the occurrence of this species from Guangdong, such a southern province is quite questionable. However, the material we examined did not differ from material from the northern provinces of China. Although it is possible that the four specimens from Guangdong were wrongly labelled, we have treated the material from Guangdong as G. minutus here.

Gyrinus paykulli Ochs, 1927

Gyrinus paykulli Ochs, 1927: 39.

\section{Material examined}

CHINA - Xinjiang • 2 ô; 新疆博湖 [Xinjiang, Bohu]; 7 Aug. 2006; 赵玲采 [Zhao Ling leg.]; SYSU - 1 ô; 新疆塔域哈尔墩河坝 [Xinjiang, Tacheng, Haerdun Heba]; 4 Aug. 2006; 赵玲采 [Zhao Ling leg.]; SYSU • 25 ふふર, 7 우; 新疆额敏河 [Xinjiang, Eminhe County]; 25 Jul. 1955; 马世骏, 夏凯龄, 陈永林采 [Ma shijun, Xia kailin, Chen Yonglin leg.]; IZCAS • 1 \%; 新疆富蕴苏普特 [Xinjiang, Fuyun County, Supute]; $47.07^{\circ}$ N, $89.46^{\circ}$ E; alt. 1065 m; 10 Jul. 2009; 采集人: 王志良 [Wang zhiliang leg.]; IZCAS.

\section{Distribution}

Widely distributed in the Palaearctic Region, known from Inner Mongolia and Xizang in China. New for Xinjiang.

\section{Gyrinus pullatus Zaitzev, 1907}

Gyrinus (Gyrinus) pullatus Zaitzev, 1908: 244.

\section{Material examined}

CHINA - Beijing • 2 ex.; 北京钓鱼台 [Beijing, Diaoyutai]; 8 May 1956; 张毅然采 [Zhang Yiran leg.]; IZCAS - 5 ex.; 北京碧云寺 [Beijing, Biyun Temple]; 24 Aug. 1956; 张毅然采 [Zhang Yiran leg.]; IZCAS ・ 1 万; 北京动物园 [Beijing Zoo]; 10 May 1955; 张毅然采 [Zhang Yiran leg.]; IZCAS ・ 1 ex.; 北京圆明园 [Beijing, Yuanmingyuan]; 17 May 1955; 张毅然采 [Zhang, Yiran leg.]; IZCAS.

\section{Distribution}

Known from China (Jilin, Liaoning), Belarus (Ryndevich et al. 2014), Finland, Korea, Russia and Sweden (Holmen 1987). New for Beijing.

\section{Gyrinus szechuanensis Ochs, 1929}

Gyrinus natator szechuanensis Ochs, 1929: 2.

Gyrinus szechuanensis - Ochs 1932: 58.

\section{Material examined}

CHINA - Yunnan・1 J゙; 云南维西塔城吧珠村 [Yunnan, Weixi, Tacheng, Baxi Village]; 19 Aug. 2013; 陈红星采 [Chen Hongxing leg.].

\section{Distribution}

Endemic to China (Sichuan). New for Yunnan. 
Genus Metagyrinus Brinck, 1955

Metagyrinus sinensis (Ochs, 1924)

Paragyrinus sinensis Ochs, 1924: 231 (original description).

Metagyrinus sinensis - Mazzoldi 1995: 165 (catalogue).

\section{Material examined}

CHINA - Guangxi • 2 우; 广西兴安县猫儿山 [Guangxi, Xing’an County, Maoershan Mout.]; 29 May 2010; 赵爽采 [Zhao Shuang leg.]; SYSU. - Guizhou・1 J; 贵州, 江口梵净山 [Guizhou, Jiangkou County, Fanjingshan Mout.]; alt. 530 m; 15 Jul. 1988; 王书永采 [Wang Shuyong leg.]; IZCAS.

\section{Distribution}

Endemic to China (Fujian, Guangdong). New for Guangxi and Guizhou.

Metagyrinus vitalisi (Peschet, 1923)

Fig. 7

Aulonogyrus vitalisi Peschet, 1923: 123.

\section{Material examined}

CHINA - Yunnan・1 9 ; 云南景东 [Yunnan, Jingdong]; alt. 1200 m; A. 孟恰茨基采 [A. Менчацкий leg.]; IZCAS.

\section{Distribution}

Known from Laos. New for China.

Orectochilini Régimbart, 1882

Genus Orectochilus Dejean, 1833

Orectochilus argenteolimbatus Peschet, 1923

Fig. 8

Orectochilus argenteolimbatus Peschet, 1923: 135.

\section{Material examined}

CHINA - Yunnan • 2 ô $^{\prime}$; Yunnan Prov., Baoshan City, Baihuangling, Jiujiezi; $25^{\circ} 18^{\prime} \mathrm{N}, 98^{\circ} 47^{\prime} \mathrm{E}$; alt. 2016 m; 19 Jun. 2015; Renchao Lin and Yudan Tang leg.; SYSU・1 9; 云南楚雄西面山上 [Yunnan, Chuxiong, Ximianshan Mt.]; alt. 2500 m; 19 May 1956; 克雷让诺夫斯基采 [Klejanovsky leg.]; IZCAS

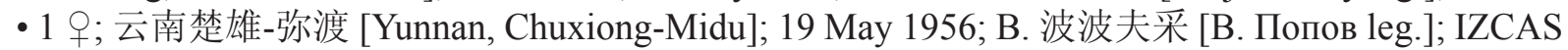
- 18 ex.; 云南西双版纳预宋 [Yunnan, Xishuangbanna, Mengsong]; alt. 1600 m; 26 Apr. 1958; 王书 永采 [Wang Shuyong leg.]; IZCAS - 42 ex.; 云南西双版纳预混 [Yunnan, Xishuangbanna, Menghun]; alt. 1200-1400 m; 24 May 1958; 洪淳培采 [Hong Chunpei leg.]; IZCAS.

\section{Distribution}

Known from Vietnam. New for China. 


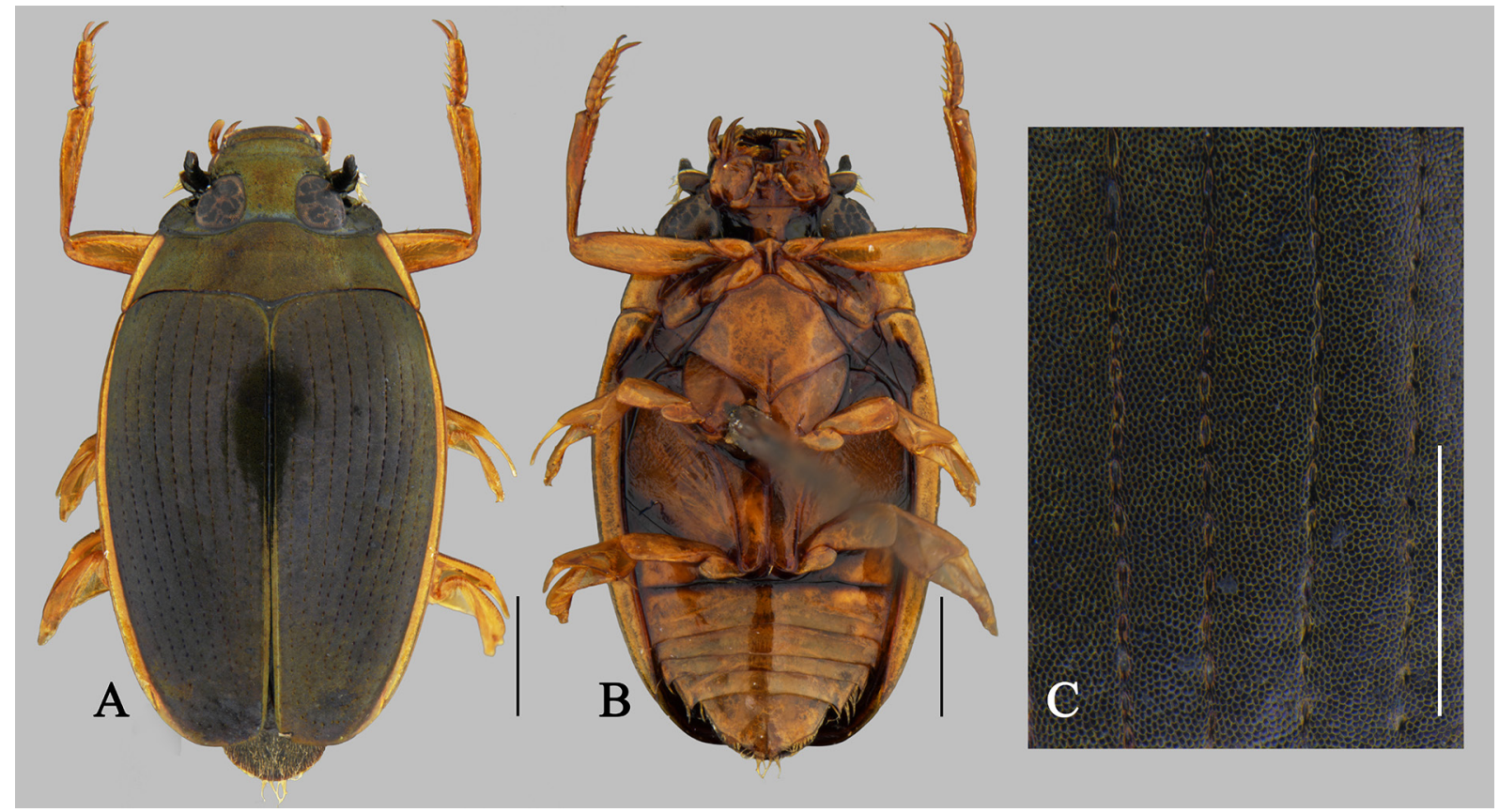

Fig. 7. Metagyrinus vitalisi (Peschet, 1923), $q$ (IZCAS). A. Habitus, dorsal view. B. Habitus, ventral view. C. Inner rows of elytral striae. Scale bars: $A-B=1 \mathrm{~mm} ; C=0.5 \mathrm{~mm}$.

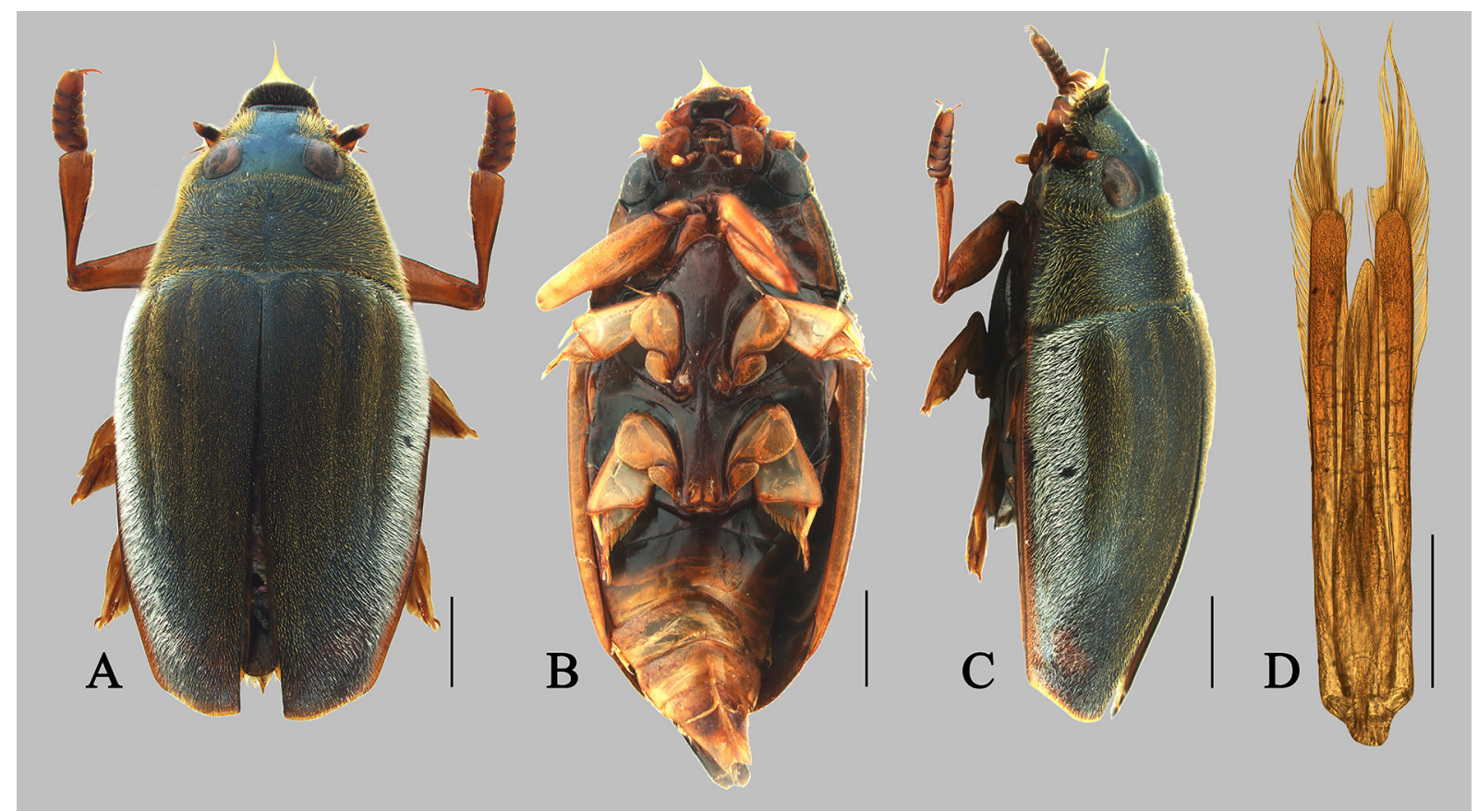

Fig. 8. Orectochilus argenteolimbatus Peschet, 1923, ô (SYSU). A. Habitus, dorsal view. B. Habitus, ventral view. C. Habitus, lateral view. D. Male genitalia. Scale bars: $A-C=1 \mathrm{~mm} ; D=0.5 \mathrm{~mm}$. 
Orectochilus fusiformis Régimbart, 1892

Orectochilus fusiformis Régimbart, 1892: 706.

\section{Material examined}

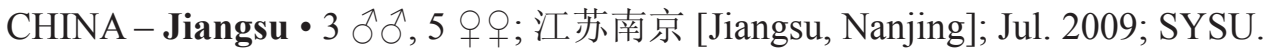

\section{Distribution}

Endemic to China (Fujian, Guangdong, Shanghai, Zhejiang). New for Jiangsu.

\section{Orectochilus murinus Régimbart, 1892}

(Figs 9A-10)

Orectochilus murinus Régimbart, 1892: 709.

\section{Material examined}

\section{Type material}

INDIA - Sikkim • 1 ठ , 1 q; mounted together. "Sikkim Kunleong, 1904-215" [register says: 'received in exchange from Régimbart'], "Orectochilus murinus Rég. ô †", "CO-TYPE”, "NHMUK014433292"; BMNH.

\section{Additional material}

CHINA - Yunnan ・ 2 9 9 云南省宁蒗彝族自治县高峰村 [Yunnan Prov., Ninglang Yi-Nationality

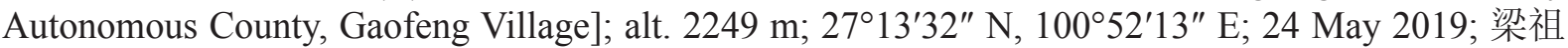

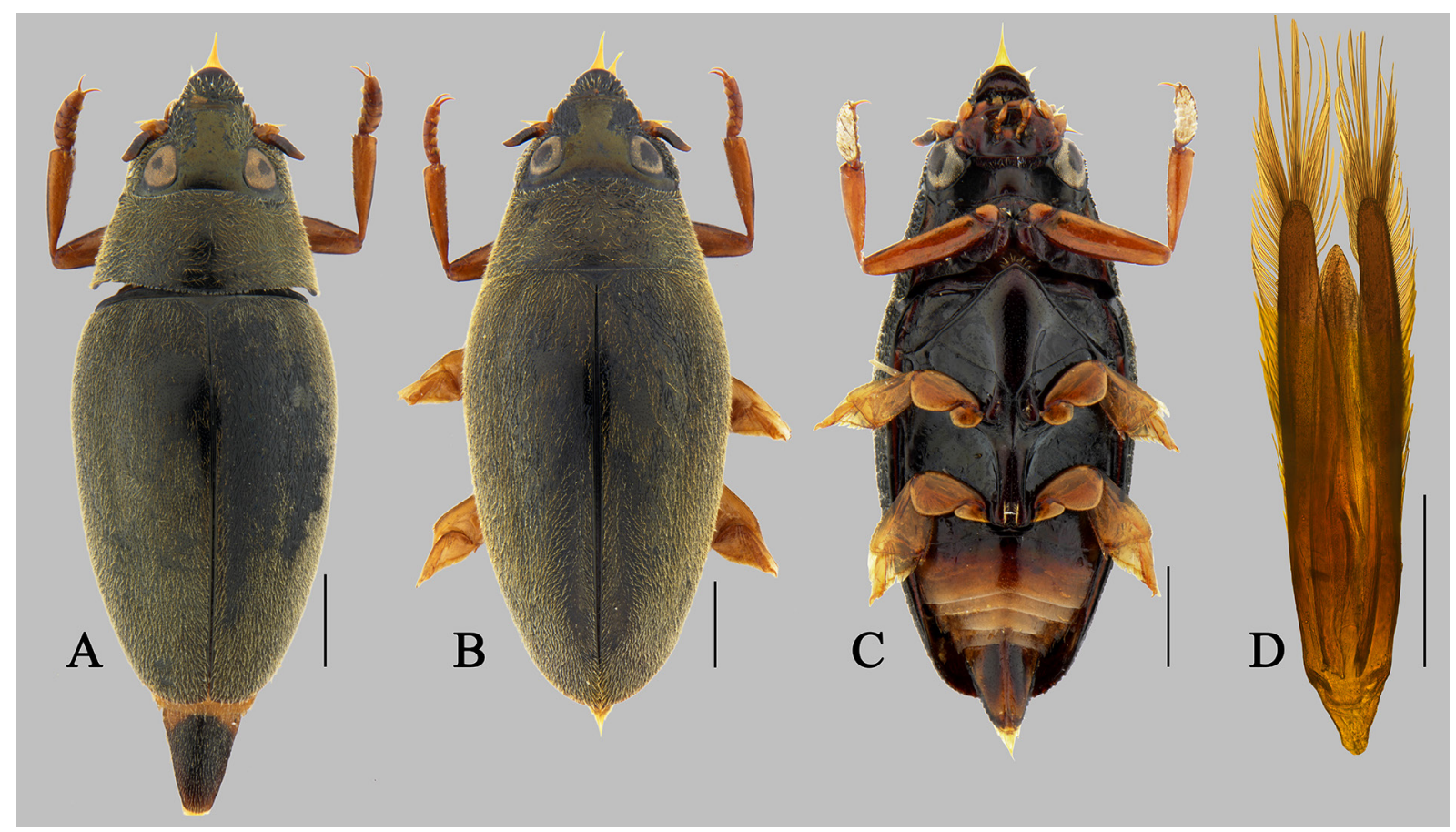

Fig. 9. Orectochilus murinus Régimbart, 1892 (SYSU). A. $\overbrace{}^{\Uparrow}$, habitus, dorsal view. B. $\uparrow$, habitus, dorsal view. C. $\hat{\jmath}$, habitus, ventral view. D. $\hat{\jmath}$, genitalia. Scale bars: $\mathrm{A}-\mathrm{C}=1 \mathrm{~mm}$; $\mathrm{D}=0.5 \mathrm{~mm}$. 
龙, 杨圳铭采 [Liang Zulong and Yang Zhenming leg.]; SYSU ・ 6 ふぶ, 9 우; Yunnan Prov., Nabanhe N. R. Nabancun; alt. 720 m; 6 May 2009; Jia-Yao Hu and Zi-wei Yin leg.; SHNU.

SIKKIM • 1 P; "Environs de Kurseong, R.P. Bretaudeau, Fry Coll, 1905-100 70770", "Orectochilus murinus Rég", "NHMUK014433293"; BMNH;•1 ex.; "Environs de Kurseong, R.P. Bretaudeau, 99.105", "O. murinus R named by Regimbart", "Received with this name from Heyne C.O.W. [C.O. Waterhouse], "NHMUK014433294"; BMNH • 1 ex.; "India Or., Sikkim, Fry Coll. 1905.100", "Orectochilus murinus Rég. Sikkim nec. Africa” [from Sikkim not Africa], "NHMUK014433295”; BMNH.

\section{Distribution}

Known from Indochina, Sikkim and India. New for China.

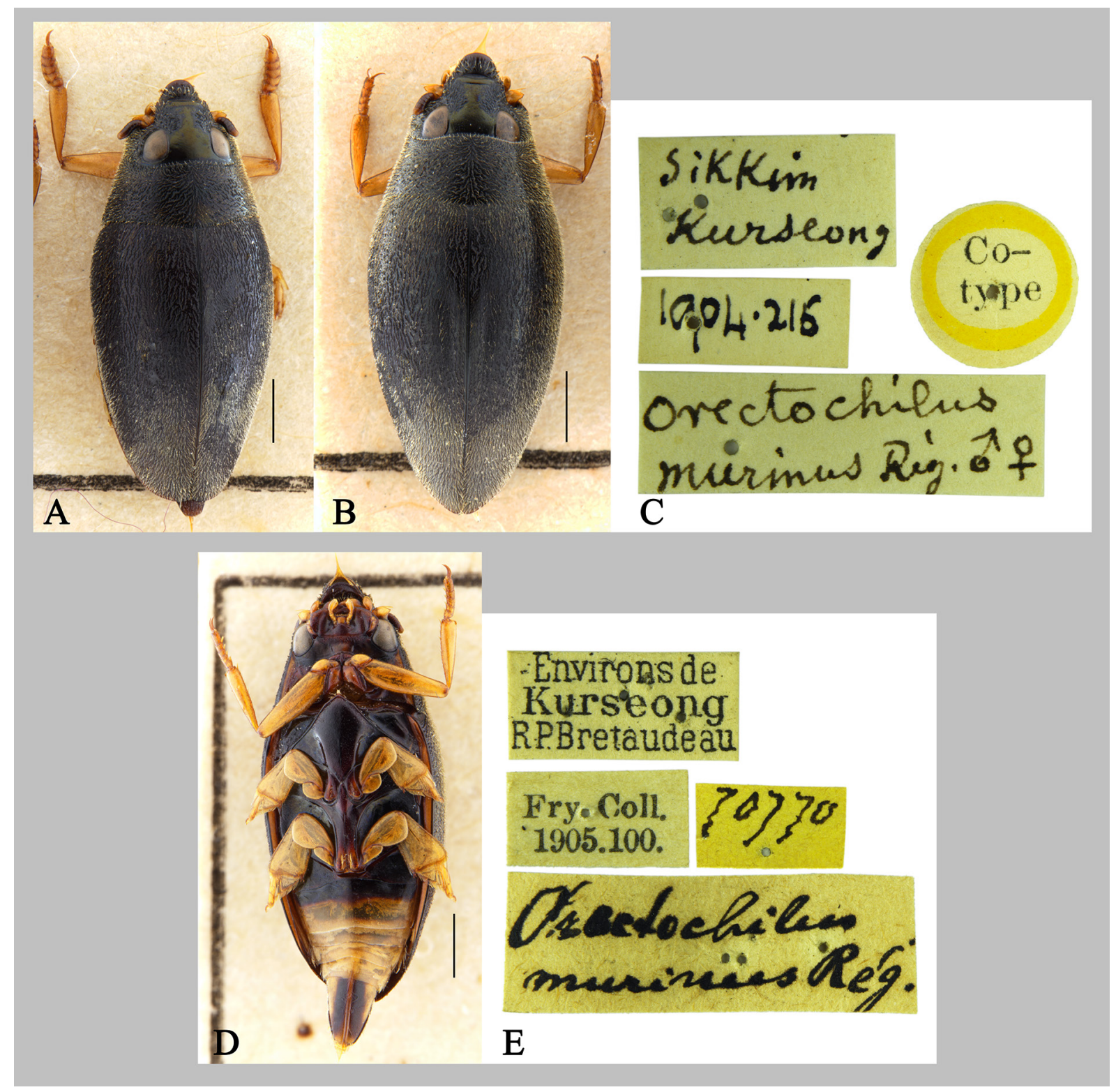

Fig. 10. Orectochilus murinus Régimbart, 1892 (BMNH). A-C. Co-type. D-E. Additional material. A. ${ }^{\lambda}$, habitus, dorsal view. B. + , habitus, dorsal view. C. Label. D. + , habitus, ventral view. E. Label. Scale bar $=1 \mathrm{~mm}$. 
Orectochilus nigroaeneus Régimbart, 1907

Orectochilus nigroaeneus Régimbart, 1907: 215.

\section{Material examined}

CHINA - Hainan・9 ex.; 海南尖峰岭三分区 [Hainan, Jianfengling Mt., third division]; 7 Jul. 1981; 何国锋采 [He Guofeng leg.]; SYSU・1 O’; 海南尖峰岭 [Hainan, Jianfengling Mt.]; 9 Jul. 1981; 饶漱 静采 [Rao Shujing leg.]; SYSU • 5 ex.; 海南尖峰岭三分区 [Hainan, Jianfengling Mt., third division]; 7 Jul. 1981; 李宗冉采 [Li Zongran leg.]; SYSU・9 ex.; 海南尖峰岭三分区 [Hainan, Jianfengling Mt., third division]; 31 Jul. 1983; 陈焕强采 [Chen Huanqiang leg.]; SYSU・ 7 ex.; 海南尖峰岭五分区 [Hainan, Jianfengling Mt., fifth division]; 8 Jul. 1981; 雷群邦采 [Lei Qunbang leg.]; SYSU • 3 ex.; 海 南尖峰岭五分区 [Hainan, Jianfengling Mt., fifth division]; 8 Jun. 1981; 雷群邦采 [Lei Qunbang leg.]; SYSU ・ 1 ex.; 海南尖峰岭五分区 [Hainan, Jianfengling Mt., fifth division]; 22 Feb. 1982; 黄治河采 [Huang Zhihe leg.]; SYSU • 5 ex.; 海南尖峰岭天池 [Hainan, Jianfengling Mt., Tianchi]; 21 Feb. 1982; 黄治河采 [Huang Zhihe leg.]; SYSU ・ 1 ex.; 海南尖峰岭天池 [Hainan, Jianfengling Mt., Tianchi]; 8 Nov. 1983; 黄治河采 [Huang Zhihe leg.]; SYSU • 4 ex.; 海南尖峰岭五分区 [Hainan, Jianfengling Mt., fifth division]; 8 Jul. 1981; 张军雄采 [Zhang Junxiong leg.]; SYSU ・ 1 ex.; 海南尖峰岭天池 [Hainan, Jianfengling Mt., Tianchi]; 7 Jul. 1981; 李胜文采 [Li Shengwen leg.]; SYSU • 3 ex.; 海南尖峰岭五分 区 [Hainan, Jianfengling Mt., fifth division]; 22 Feb 1982; 龙建国采 [Ling Jianguo leg.]; SYSU • 2 ex.; 海南尖峰岭五分区 [Hainan, Jianfengling Mt., fifth division]; 10 Feb. 1984; 陆高平采 [Lu Gaoping leg.]; SYSU • 3 ex.; 海南尖峰岭五分区 [Hainan, Jianfengling Mt., fifth division]; 26 Feb. 1982; 张昆 智采 [Zhang Kunzhi leg.]; SYSU ・ 1 ex.; 海南尖峰岭五分区 [Hainan, Jianfengling Mt., fifth division]; Aug. 1981; 华立中采 [Hua Lizhong leg.]; SYSU ・ 1 ex.; 海南尖峰岭五分区 [Hainan, Jianfengling Mt., fifth division]; 22 Feb. 1982; 龙永成采 [Long Yongcheng leg.]; SYSU ・ 1 ex.; 海南尖峰岭五分 区 [Hainan, Jianfengling Mt., fifth division]; 8 Aug. 1981; 广永泉采 [Kuang Yongquan leg.]; SYSU - 1 ex.; 海南尖峰岭五分区 [Hainan, Jianfengling Mt., fifth division]; 8 Aug. 1981; SYSU • 1 ex.; 海 南尖峰岭三分区 [Hainan, Jianfengling Mt., third division]; 13 Oct. 1983; 保护站采 [Reserve station leg.]; SYSU ・ 1 ex.; 海南尖峰岭天池 [Hainan, Jianfengling Mt., Tianchi]; 21 Feb. 1982; 陈振耀采 [Chen Zhenyao leg.]; SYSU • 1 ex.; 海南尖峰岭天池 [Hainan, Jianfengling Mt., Tianchi]; 24 Feb. 1982; 陈振耀采 [Chen Zhenyao leg.]; SYSU • 22 ex.; 海南尖峰岭, 第三, 五分区 [Hainan, Jianfengling Mt., third and fifth division]; 9 May 2011; 赵爽采 [Zhao Shuang leg.]; SYSU. - Henan・1 9 ; 河南信阳

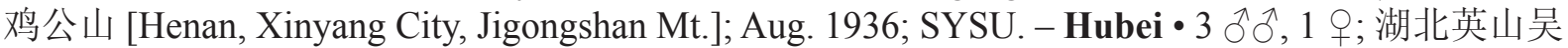
家山 [Hubei, Yingshan County, Wujiashan Mt.]; 12 Jul. 2006; 石否采 [Shi Lei leg.]; SYSU. - Jiangxi - 26 ex.; 江西龙南九连山 [Jiangxi, Longnan County, Jiulianshan Mout.]; 12-13 Aug. 2008; 贾凤龙 采 [Jia Fenglong leg.]; SYSU • 1 ô, 1 o; Jiangxi Prov. Longnan County, Jiulianshan Nature Reserve;

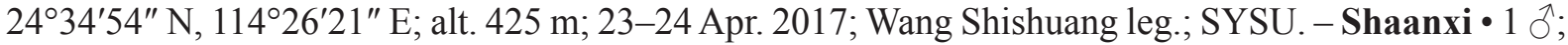
陕西西安楼观台 [Shaanxi, Xi'an City, Louguantai]; 24 Jul. 2001; 赵玲采 [Zhao Lin leg.]; SYSU.

\section{Distribution}

Endemic to China (Fujian, Guangdong). New for Hainan, Henan, Hubei, Jiangxi and Shaanxi.

\section{Orectochilus obscuriceps Régimbart, 1907}

Orectochilus obscuriceps Régimbart, 1907: 215.

\section{Material examined}

CHINA - Guangdong - 21 ex.; 广东韶关南岭国家自然保护区, 溪流 [Guangdong, Shaoguan,

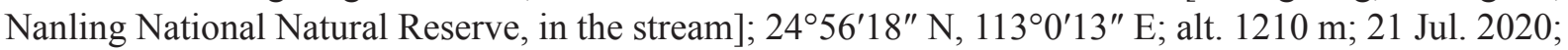
leg. Liang Zulong, Yang Zhenming; SYSU. - Guangxi • 5 $\widehat{\partial}, 9$ q $९$; Guangxi Prov., Jiuwandashan, Yangmeiao; $25^{\circ} 11^{\prime} 42^{\prime \prime}$ N, 108 38'51" E; 20 Jul. 2015; Renchao Lin and Yudan Tang leg.; SYSU. 
LIANG Z. et al., Three new species of Patrus with additional records of Gyrinidae from China

\section{Distribution}

Endemic to China (Shaanxi, Sichuan). New for Guangdong and Guangxi.

Orectochilus obtusipennis Régimbart, 1892

Orectochilus obtusipennis Régimbart, 1892: 712.

\section{Material examined}

CHINA - Chongqing ・ 1 ơ; 重庆, 巫山县 [Chongqing, Wushan County]; alt. 200-1800 m; 16 Aug. 2006; 张小蓉采 [Zhang Xiaorong leg.]; SYSU. - Guangdong - 1 `; 广东连县大东山 [Guangdong, Lianxian County, Dadongshan Mout.]; 13 Jul. 1998; 蔡于琛采 [Cai Yuchen leg.]; SYSU ・ 1 गे; 广 东连县大东山 [Guangdong, Lianxian County, Dadongshan Mout.]; 13 Jul. 1998; 陈翠萍采 [Chen Cuiping leg.]; SYSU. - Henan • 2 + $ᄋ$; 河南信阳鸡公山 [Henan, Xinyang City, Jigongshan Mount.]; Aug. 1926; SYSU. - Hunan • 1 \%; Hunan Province, Yanling Co., Nanfengmian, mixed forest, shrub,

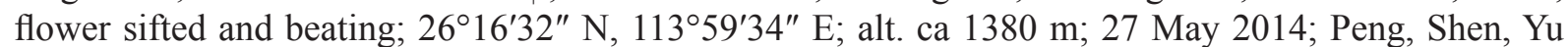

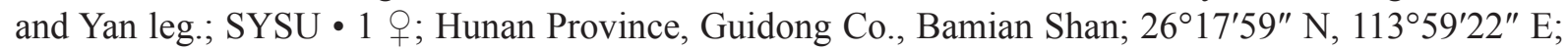
alt. 1030 m; 31 May 2014; Peng, Shen, Yu and Yan leg.; light trap; SYSU. - Jiangxi • 1 \%; W Jiangxi,

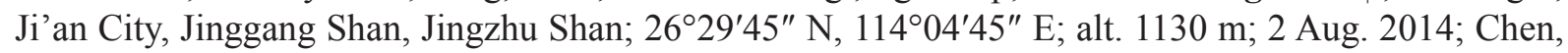
$\mathrm{Hu}, \mathrm{Lv}$ and Yu leg.; in the stream; SHNU. - Jiangsu • 1 \%; 江苏南京 [Jiangsu, Nanjing]; Jul. 2009; SYSU. - Sichuan・1 0 ; 四川省青川县青溪镇河口里村 [Sichuan Prov., Qingchuan County, Qingxi Town, Hekouli]; alt. 1127 m; 32³1'31" N, 10450'22" E; 11 May 2019; 梁祖龙, 杨圳铭采 [Liang Zulong and Yang Zhenming leg.]; SYSU.

\section{Distribution}

Endemic to China. Known from Shanghai and Zhejiang. New for Chongqing, Guangdong, Henan, Hunan, Jiangxi, Jiangsu and Sichuan.

Genus Patrus Aubé, 1838

Patrus annandalei (Ochs, 1925) comb. nov.

Fig. 11

Orectochilus annandalei Ochs, 1925: 203. (original description).

Orectochilus (Patrus) annandalei - Ochs 1930: 20.

\section{Material examined}

CHINA - Hainan ・ 1 O ; 海南尖峰岭天池 [Hainan, Jianfengling Mt., Tianchi]; 21 Mar. 1983; 梁少营 采 [Liang Shaoying leg.]; SYSU • 7 ex.; 海南岛尖峰岭 [Hainan, Jianfengling]; 18 Aug. 1963; SYSU - 3 ex.; 海南尖峰岭 [Hainan, Jianfengling]; 4 Feb. 1981; 陈振耀 [Chen Zhenyao leg.]; SYSU • 2 đo ô; 海南陵水吊罗山 [Hainan, Lingshui, Diaoluoshan Mt.]; 26 Dec. 1983; 李济才采 [Li Jicai leg.]; SYSU.

VIETNAM • 2 qo; “"Tonkin: Hoabinh. A. de Cooman. B. M. 1940-13”; IZCAS.

\section{Distribution}

Known from India. New for China and Vietnam. 
Patrus chalceus (Ochs, 1936)

Orectochilus chalceus Ochs, 1936: 605. (original description).

Orectochilus (Patrus) chalceus - Mazzoldi 1995: 164 (catalogue).

Patrus chalceus - Hájek \& Fery 2017: 28 (catalogue).

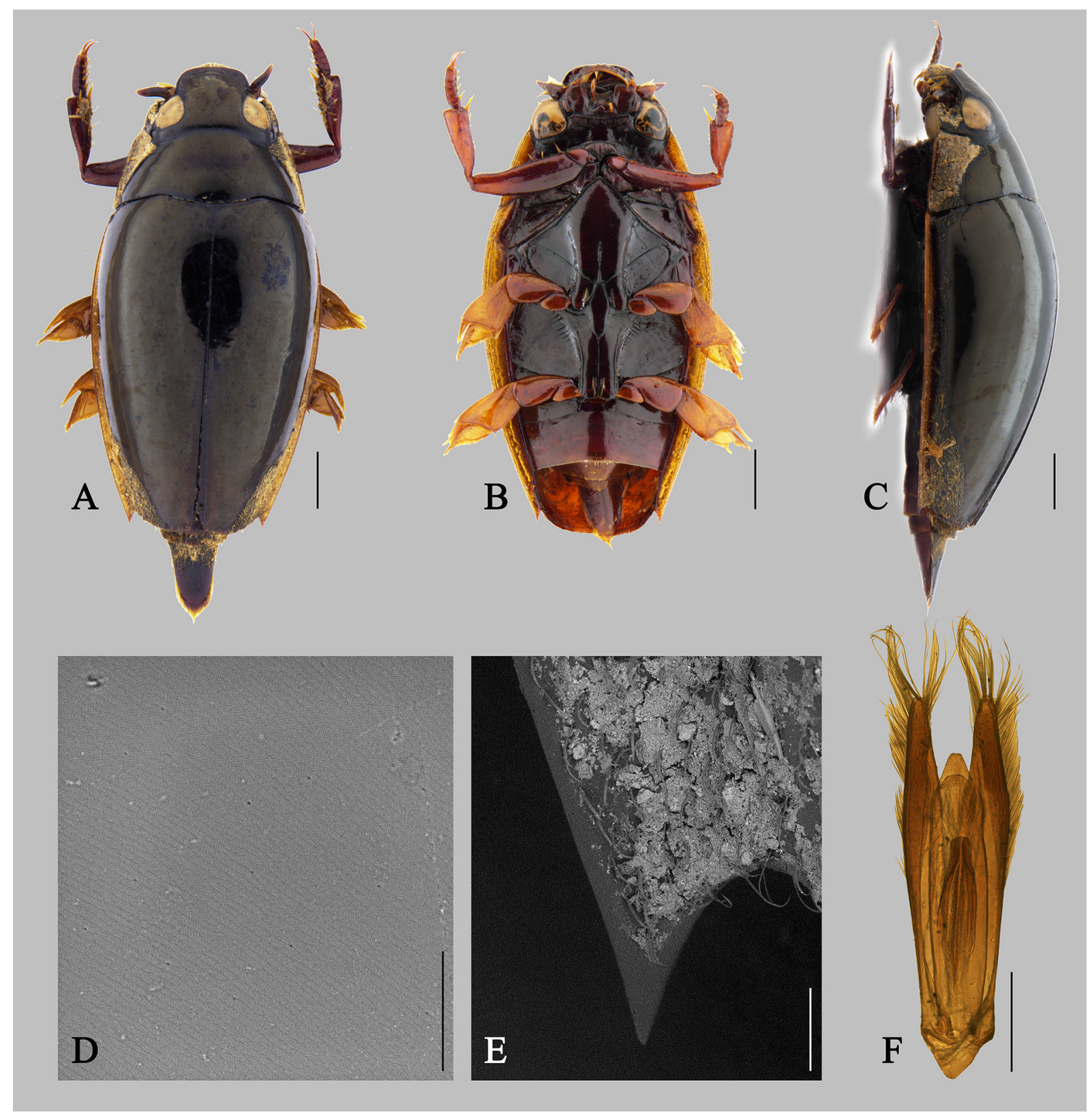

Fig. 11. Patrus annandalei (Ochs, 1925) (SYSU). A. + , habitus, dorsal view. B. $q$, habitus, ventral view. C. + , habitus, lateral view. D. $q$, surface sculpture on elytra. E. $q$, epipleural angle. F. $\hat{\sigma}$, male genitalia. Scale bars: $A-C=1 \mathrm{~mm} ; \mathrm{D}=30 \mu \mathrm{m} ; \mathrm{E}=100 \mu \mathrm{m} ; \mathrm{F}=0.5 \mathrm{~mm}$. 


\section{Material examined}

CHINA - Hainan • 1 J ; 海南尖峰岭五分区 [Hainan, Jianfengling Mt., fifth division]; 8 Jul. 1981; 饶漱靖采 [Rao shujing leg.]; SYSU・1 9 ; 海南尖峰岭天池 [Hainan, Jianfengling Mt., Tianchi]; Jul. 1981; SYSU. - Jiangxi ・ 1 Ô, 1 क ; 江西井冈山弯坑 [Jiangxi, Jinggangshan Mt.]; 29 Apr. 2011; 采

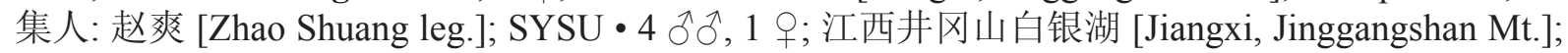
alt. 880 m; 23 Apr. 2011 ; 采集人: 赵爽 [Zhao Shuang leg.]; SYSU・1 ठ; 江西井冈山白银湖 [Jiangxi, Jinggangshan Mt., Baiyinhu Lake]; alt. 800 m; 27 Apr. 2011; 采集人: 贾凤龙 [Jia Fenglong leg.]; SYSU - 2 + 9 ; 江西井冈山大井-龙潭风景区 [Jiangxi, Jinggangshan Mt., Dajing-Longtang Scenic Area]; 3 Oct. 2010; 赵爽采 [Zhao Shuang leg.]; SYSU.

\section{Distribution}

Endemic to China (Guangdong). New for Hainan and Jiangxi.

Patrus coomani (Peschet, 1925) comb. nov. Fig. 12

Orectochilus coomani Peschet, 1925: 253 (original description).

\section{Material examined}

CHINA - Guangdong • 1 o, 2 ㅇ; ; 深圳市大鹏半岛坪头岭 [Shenzhen, Dapeng Peninsula, Pingtouling

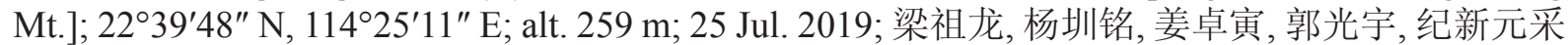
[Liang Zulong, Yang Zhenming, Jiang Zuoyin, Guo Guangyu and Ji Xinyuan leg.]; SYSU • 1 足; 广东省 深圳市大鹏半岛田头山 [Shenzhen, Dapeng Peninsula, Tiantoushan Mt.]; 22 ${ }^{\circ} 40^{\prime} 12^{\prime \prime}$ N, 114²4'44" E; alt. 208.4 m; 30 Jul. 2019; 杨圳铭, 姜卓寅, 郭光宇, 纪新元采 [Yang Zhenming, Jiang Zuoyin, Guo

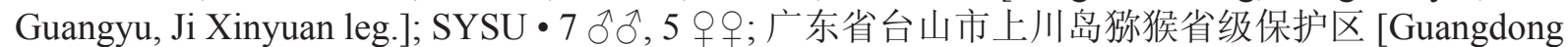
Prov., Taishan City, Shangchuan Island Macaque Provincial Nature Reserve]; 21 ${ }^{\circ} 44^{\prime} 36^{\prime \prime}$ N, $112^{\circ} 50^{\prime} 33^{\prime \prime}$ E; alt. 10 m; 18 Jan. 2019; 贾凤龙, 梁祖龙采 [Jia Fenglong and Liang Zulong leg.]; SYSU • 2 $\hat{\jmath}, 1$; ; 广东省台山市上川岛狝猴省级保护区 [Guangdong Prov., Taishan City, Shangchuan Island Macaque

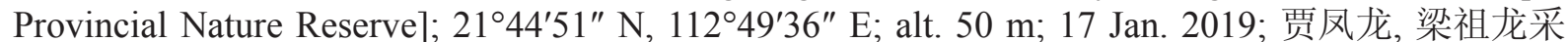
[Jia Fenglong and Liang Zulong leg.]; SYSU ・ 1 9; 广东省台山市上川岛猕猴省级保护区石背潭 [Guangdong Prov., Taishan City, Shangchuan Island Macaque Provincial Nature Reserve, Shibeitang]; $21^{\circ} 46^{\prime} 1^{\prime \prime}$ N, 112 $49^{\prime} 2^{\prime \prime}$ E; alt. 20 m; 19 Jan. 2019; 贾风龙, 梁祖龙采 [Jia Fenglong and Liang Zulong leg.]; SYSU ・ 1 万’; 广东肇庆鼎湖山 [Guangdong, Zhaoqing, Dinghushan Mt.] 19 Jun. 1958; 利翠英 采 [Li Cuiying leg.]; SYSU・1 Ô, 4 우; 广东肇庆鼎湖山 [Guangdong, Zhaoqing, Dinghushan Mt.]; 13 Oct. 1958; SYSU • 1 Ő, 3 q 9 ; 广东鼎湖山 [Guangdong, Dinghushan Mt.]; 8 Jul. 1964; 吴思添采 [Wu Sitian leg.]; SYSU・1 O; 肇庆鼎湖山 [Zhaoqing, Dinghushan Mt.]; 3 Nov. 1974; 春强采 [Chun Qiang leg.]; SYSU • 1 \% ; 广东高要县鼎湖山 [Guangdong, Gaoyao County, Dinghushan Mt.]; 15 Jul. 1964; 何目秀采 [He Muxiu leg.]; SYSU • 1 O ; 和平县九连山 [Heping County, Jiulianshan Mt.]; 26 Aug. 1986; 陈振耀采 [Chen Zhenyao leg.]; SYSU ・ 1 o; 广东连县大东山 [Guangdong, Lianxian County, Dadongshan Mt.]; 4 Sep. 1994; 彭红采 [Peng Hong leg.]; SYSU ・ 1 ○, 2 q 우 ; 广东高明鹿田 [Guangdong Gaoming, Lutian]; 14 May 2004; 贾凤龙, 方小端采 [Jia Fenglong and Fang Xiaoduan leg.]; SYSU.

\section{Distribution}

Known from Vietnam. New for China. 
Patrus haemorrhous (Régimbart, 1892)

Figs 13-14

Orectochilus haemorrhous Régimbart, 1892: 706 (original description).

Orectochilus haemorrhous var. lobiger Régimbart, 1907: 214 (original description).

Patrus haemorrhous - Hájek \& Fery 2017: 28 (catalogue).

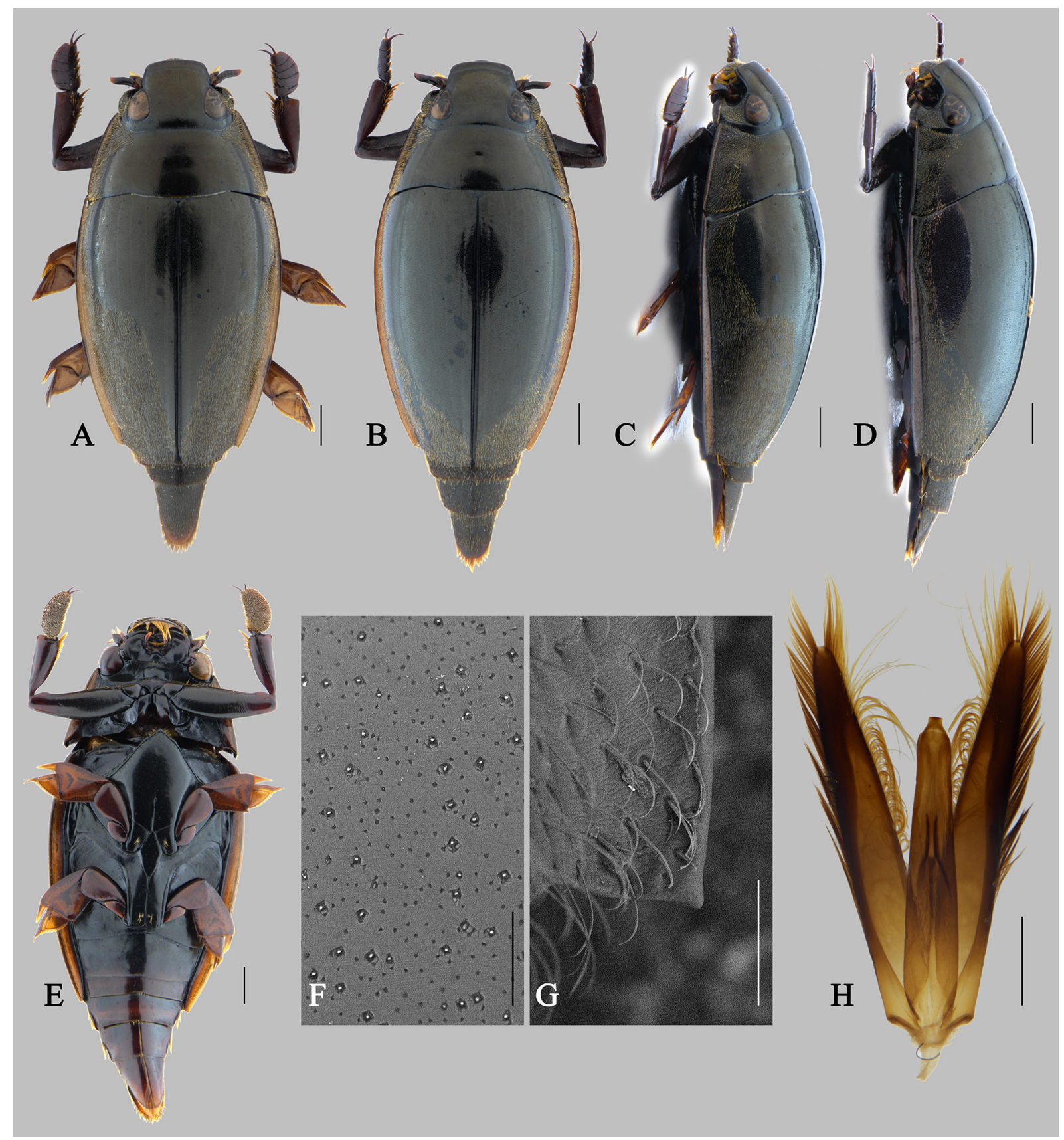

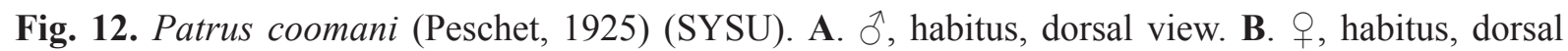

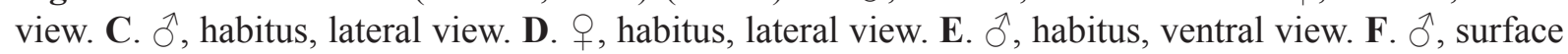
sculpture on elytra. G. $\hat{\partial}$, epipleural angle. H. $\hat{\partial}$, genitalia. Scale bars: $A-E=1 \mathrm{~mm} ; F-G=100 \mu \mathrm{m} ; \mathrm{H}$ $=0.5 \mathrm{~mm}$. 


\section{Material examined}

Syntype

INDIA - Tamil Nadu • 1 §, 3 क $\%$; Madras; 1908; Maurice Régimbart leg.; MNHN EC11801 to EC11804.

CHINA - Yunnan • 1 q; Yunnan Prov., Xishuangbanna, Botanical garden; 5-6 Jul. 2003; Hu and Tang leg; SHNU.

\section{Distribution}

Known from India and Pakistan. New for China.

Patrus jilanzhui (Mazzoldi, 1998)

Orectochilus (Patrus) jilanzhui Mazzoldi, 1998: 140, fig. 3a-d (original description).

Patrus jilanzhui - Hájek \& Fery 2017: 29 (catalogue).

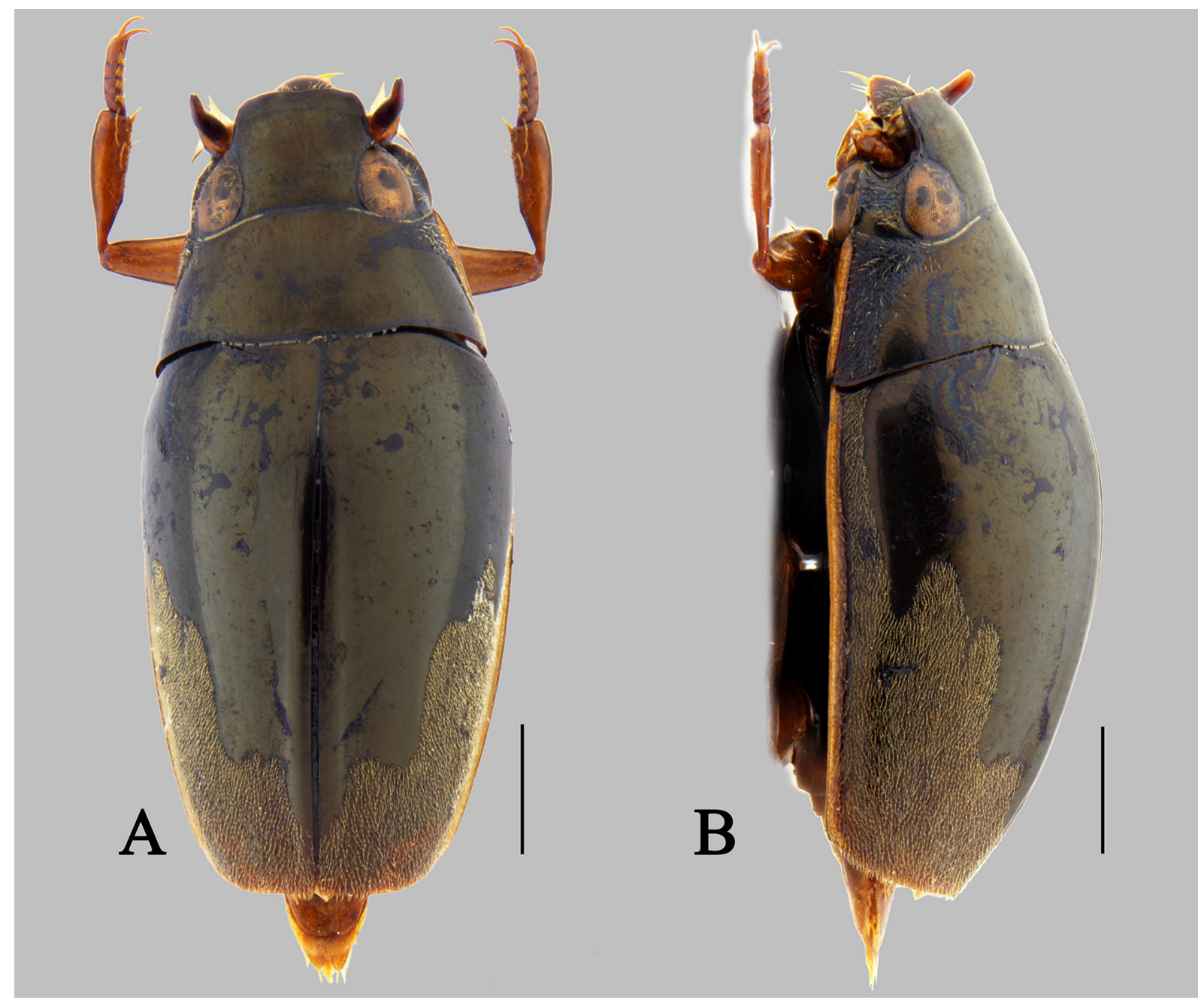

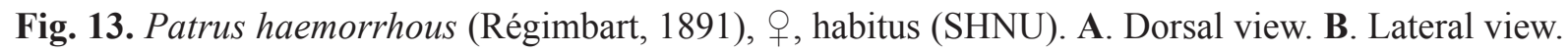
Scale bar $=1 \mathrm{~mm}$. 


\section{Material examined}

CHINA - Guangdong • 1 乃; 广东肇庆鼎湖山 [Guangdong, Zhaoqing, Dinghushan Mt.]; 19 Aug. 1958; 利翠英采 [leg. Li Cuiying.]; SYSU - 1 q; 广东连县大东山 [Guangdong, Lianxian County, Dadongshan Mt.]; 13 Aug. 1998; 谭乐采 [Tan Le leg.]; SYSU.

\section{Distribution}

Endemic to China. Known from Hainan. New for Guangdong.

Patrus landaisi (Régimbart, 1892)

Orectochilus landaisi Régimbart, 1892: 692 (original description).

Orectochilus (Patrus) landaisi - Mazzoldi 1995: 164 (catalogue).

Patrus landaisi - Hájek \& Fery 2017: 29 (catalogue).
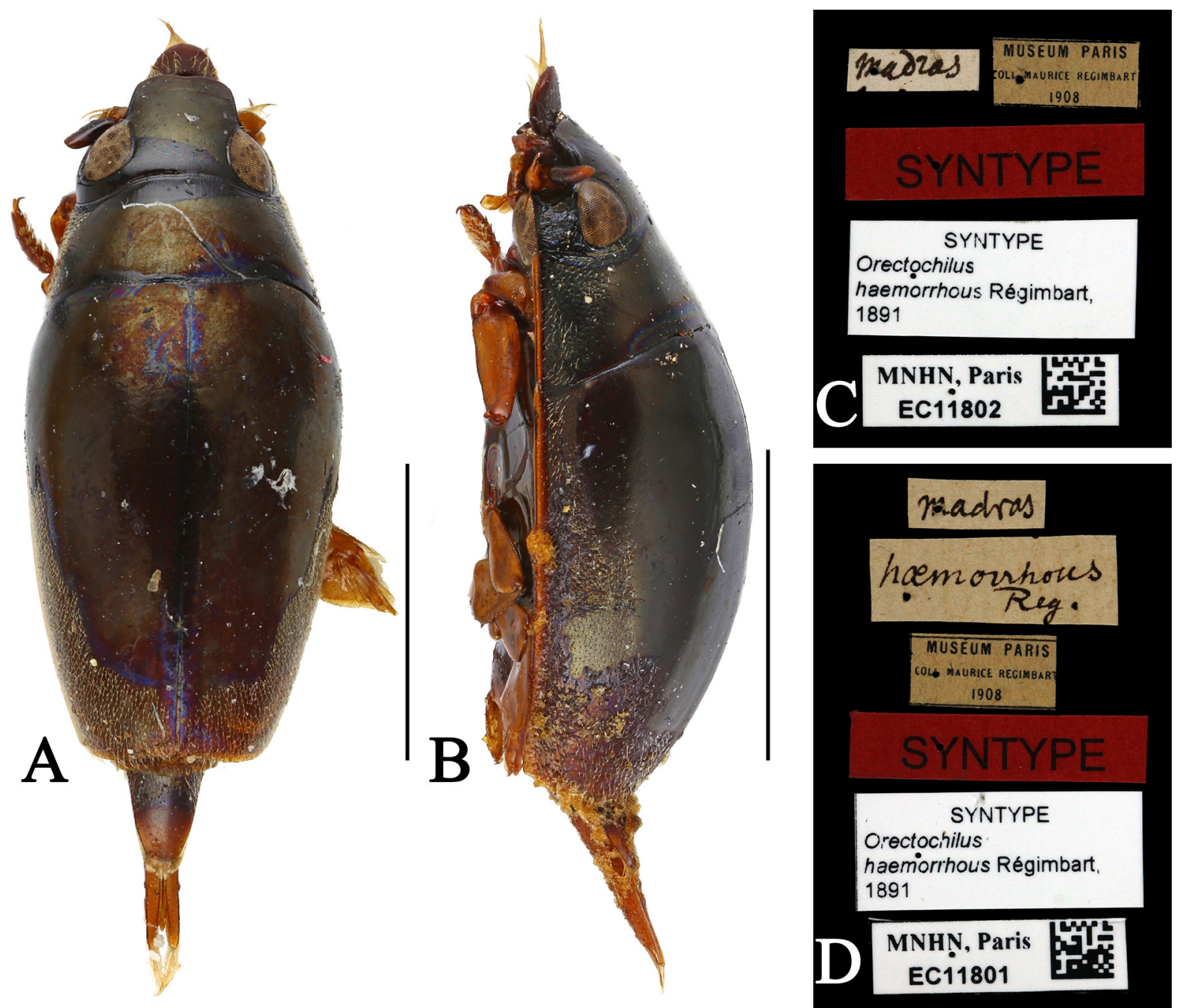

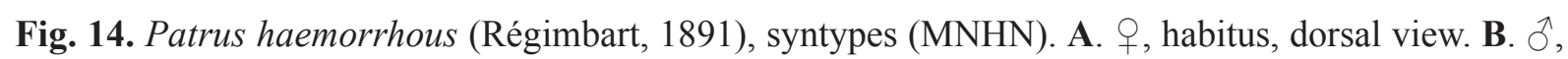
habitus, lateral view. C. Label of specimen A. D. Label of specimen B. Figures provided by Antoine Mantilleri. Scale bars $=2 \mathrm{~mm}$. 


\section{Material examined}

CHINA - Guangxi ・1 Õ, 4 q ; 广西隆林 [Guangxi, Longlin]; 26 May 1977; 黄治河采Huang Zhihe [leg.]; SYSU ・ 1 Ô, 1 q; 广西靖西底定 [Guangxi, Jingxi City, Diding Village]; 8 Aug. 2010; 黄建华 采 [Huang Jianhua leg.]; SYSU.

\section{Distribution}

Known from China (Guizhou, Yunnan), Vietnam and Laos. New for Guangxi.

Patrus marginepennis angustilimbus (Ochs, 1925)

Fig. 15

Orectochilus marginipennis angustilimbus Ochs, 1925: 202 (original description).

Patrus marginepennis angustilimbus - Hájek \& Fery 2017: 29 (catalogue).

\section{Material examined}

CHINA - Yunnan・1 o; 云南小槛养 [Yunnan, Xiaomengyang]; alt. 810 m; 25 Mar. 1957; 蒲富基采 [Pu Fuji leg.]; IZCAS.

\section{Distribution}

Known from India. New for China.

Patrus marginipennis parvilimbus (Ochs, 1925)

Orectochilus marginipennis parvilimbus Ochs, 1925: 202 (original description).

Orectochilus (Patrus) marginepennis parvilimbus - Mazzoldi 1995: 164 (catalogue).

Patrus marginepennis parvilimbus - Hájek \& Fery 2017: 29 (catalogue).

\section{Material examined}

CHINA - Fujian • 1 đ ; 福建, 建阳黄坑桂林 [Fujian, Jianyang, Huangkeng, Guilin]; alt. 270-390 m; 5 Apr. 1960; 马成林采 [Ma Chenlin leg.]; IZCAS. - Hainan • 1 ex.; 海南尖峰岭 [Hainan, Jianfengling Mt.]; 13 Oct. 1983; 利翠英采 [Li Cuiying leg.]; SYSU • 1 ex.; 海南尖峰岭 [Hainan, Jianfengling Mt.]; 19 Dec. 1983; 利翠英采 [Li Cuiying leg.]; SYSU.

\section{Distribution}

Endemic to south China. Known from Guangdong. New for Fujian and Hainan.

Patrus melli (Ochs, 1925)

Orectochilus melli Ochs, 1925: 197 (original description).

Orectochilus (Patrus) melli - Mazzoldi 1995: 165 (catalogue).

Patrus melli - Hájek \& Fery 2017: 29 (catalogue)

\section{Material examined}

CHINA - Guangxi • 1 §, 3 $q$ क ; Guangxi Prov., Jinxiu County; 24 Jul. 2011; alt. 850-950 m; PENG Zhong leg.; SHNU. - Jiangxi ・ 1 ô, 1 क ; 江西井冈山香洲 [Jiangxi, Jinggangshan Mt., Xiangzhou]; 13 Sep. 2011; 采集人: 杨立军、李锦伟、成牧春 [Yang Lijun, Li Jinwei and Cheng Muchun leg.]; 
SYSU. - Zhejiang • 1 §, 1 क; Zhejiang Prov., Longwang Shan; 4 Oct. 2003; Li-Zhen Li leg; SHNU

- 1 q; Zhejing Prov., Mt. Longwang; alt. 300-500 m; 24 Apr. 2004; Huang and Chi leg.; SHNU.

\section{Distribution}

Endemic to China (Fujian, Guangdong, Hong Kong). New for Guangxi, Jiangxi and Zhejiang.

Patrus procerus (Régimbart, 1884) comb. nov.

Fig. 16

Orectochilus procerus Régimbart, 1884: 415 (original description).

\section{Material examined}

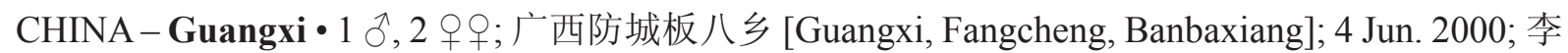
文柱采 [Li Wenzhu leg.]; SYSU.

\section{Distribution}

Known from Cambodia. New for China.

Patrus productus (Régimbart, 1884)

Orectochilus productus Régimbart, 1884: 422, 1883: pl. 12 fig. 130 (original description).

Orectochilus (Patrus) productus - Mazzoldi 1995: 165 (catalogue).

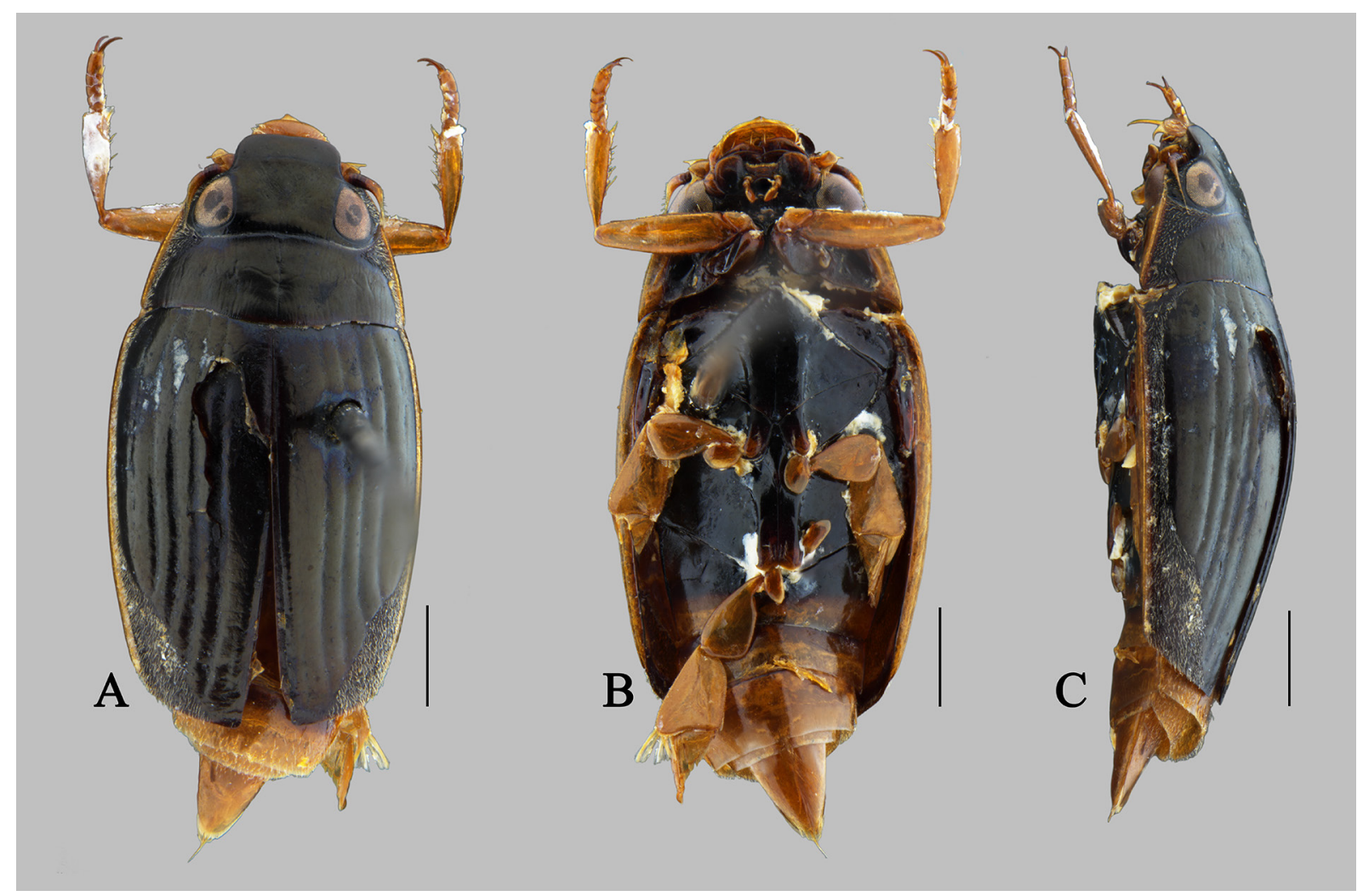

Fig. 15. Patrus marginepennis angustilimbus (Ochs, 1925), + , habitus (IZCAS). A. Dorsal view. B. Ventral view. C. Lateral view. Scale bars $=1 \mathrm{~mm}$. 
Patrus productus - Hájek \& Fery 2017: 29 (catalogue).

\section{Material examined}

CHINA - Guangdong • 10 ex. 广东珠海横琴岛 [Guangdong, Zhuhai, Hengqin Island]; 12 Jul. 2005; 采集人: 贾奥 [Jia Yue leg.]; SYSU - 2 ô ô, 1 o ; 广东省肇庆市丹霞山 [Guangdong, Zhaoqing, Dinghushan Mt.]; 11 Jun. 2018; 梁祖龙采 [Liang Zulong leg.]; SYSU • 24 ex.; 深圳坪山区马峦山

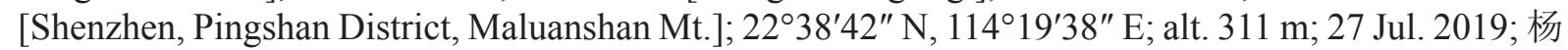
圳铭, 姜卓寅, 郭光宇, 纪新元采 [Yang Zhenming, Jiang Zuoyin, Guo Guangyu and Ji Xinyuan leg.]; SYSU.

\section{Distribution}

Widespread in the Oriental Region, known from Hainan, Hong Kong, Jiangsu, Macao in China. New for Guangdong.

Patrus severini (Régimbart, 1892)

Orectochilus severini Régimbart, 1892: 700 (original description).

Orectochilus (Patrus) severini - Mazzoldi 1995:165 (catalogue).

Patrus severini - Hájek \& Fery 2017: 29 (catalogue).

\section{Material examined}

CHINA - Jiangsu・ 1 q, 1 ô; 江苏南京 [Jiangsu, Nanjing]; Jul. 2009; SYSU.

\section{Distribution}

Endemic to China. Known from ?Guangdong, Guizhou, and Hong Kong. New for Jiangsu.

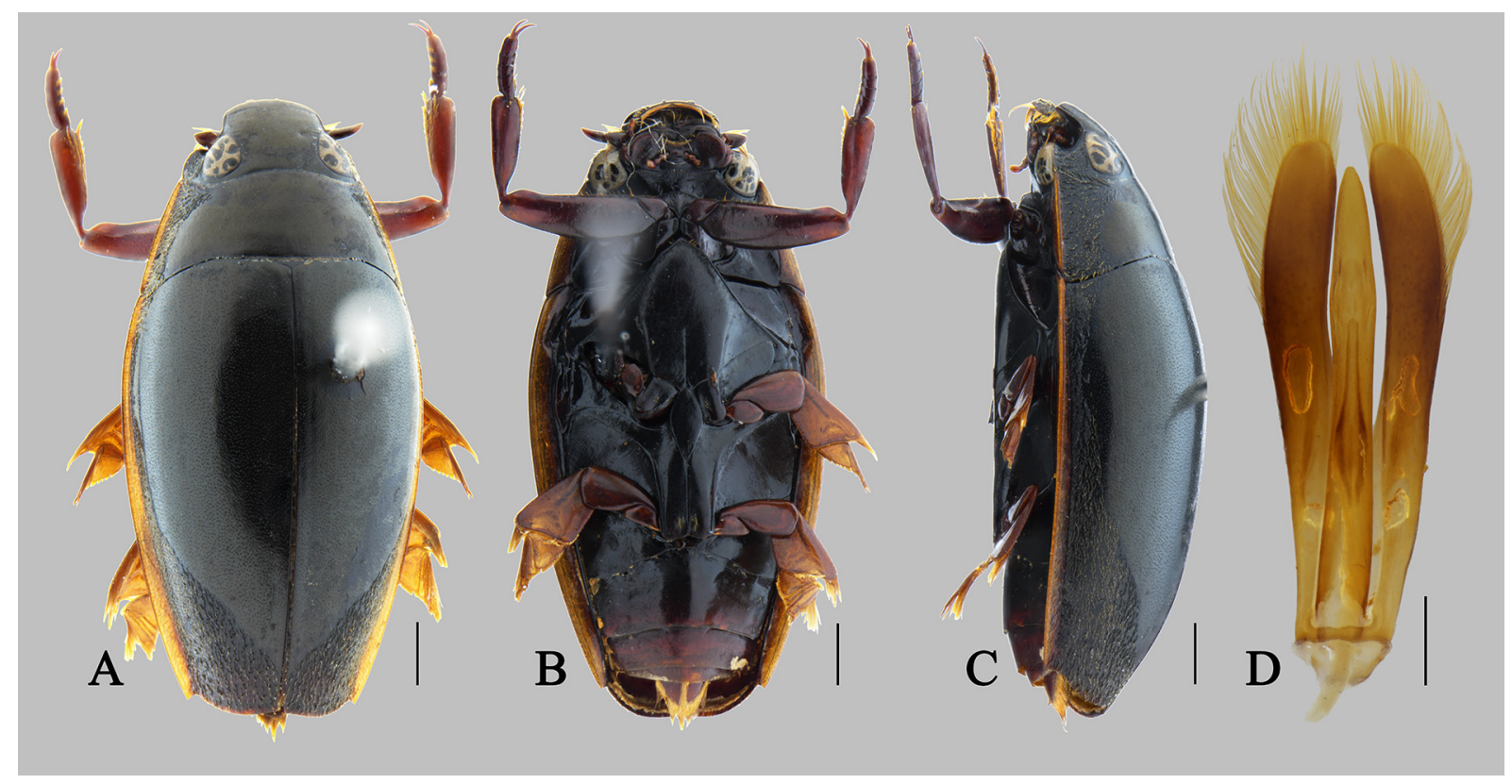

Fig. 16. Patrus procerus (Régimbart, 1884) (SYSU). A. + , habitus, dorsal view. B. + , habitus, ventral view. C. , habitus, lateral view. D. $\hat{O}$, genitalia. Scale bars: $A-C=1 \mathrm{~mm} ; \mathrm{D}=0.5 \mathrm{~mm}$. 
Patrus wangi (Mazzoldi, 1998)

Orectochilus (Patrus) wangi Mazzoldi, 1998: 145, figs 1, 4 (original description).

Patrus wangi - Hájek \& Fery 2017: 29 (catalogue).

\section{Material examined}

CHINA - Guangdong • 1 \%; 广东肇庆鼎湖山 [Guangdong, Zhaoqing, Dinghushan Mt.]; Jul. 1973;

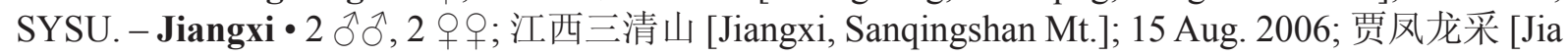
Fenglong leg.]; SYSU.

\section{Distribution}

Endemic to China (Anhui, Zhejiang). New for Guangdong and Jiangxi.

Patrus wui (Ochs, 1932)

Orectochilus wui Ochs, 1932: 57 (original description).

Orectochilus (Patrus) wui - Mazzoldi 1995: 165 (catalogue).

Patrus wui - Hájek \& Fery 2017: 29 (catalogue).

\section{Material examined}

CHINA - Guangdong・15 ex.; 广东肇庆黑石顶 [Guangdong, Zhaoqing, Heishiding]; 25 Jul. 2018; 贾风龙采 [Jia Fenglong leg.]; SYSU • 4 ex.; 广东封开县黑石顶 [Guangdong, Fengkai, Heishiding]; $23^{\circ} 31^{\prime} \mathrm{N}, 111^{\circ} 52^{\prime}$ E; 20-22 Sep. 2014; 贾凤龙, 唐余丹采 [Jia Fenglong, Tang Yudan leg.]; SYSU • 7 ex.;

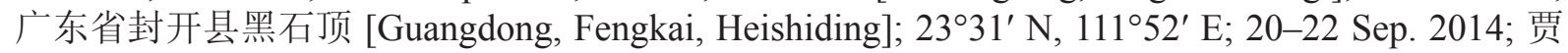
凤龙, 林仁超, 唐余丹采 [Jia Fenglong, Lin Renchao, Tang Yudan leg.]; SYSU • 2 ex.; 广东封开黑石 顶 [Guangdong, Fengkai, Heishiding]; 11 Jul. 2000; 罗菁采 [Luo Jing leg.]; SYSU ・ 2 ô $\delta$; 广东封 开黑石顶 [Guangdong, Fengkai, Heishiding]; 5 Jul. 1987; 钟声雄采 [Zhong Shengxiong leg.]; SYSU - 1 J ; 广东封开黑石顶 [Guangdong, Fengkai, Heishiding]; 3 Jul. 1987; 陈邵峰采 [Chen Shaofeng leg.]; SYSU ・ 1 ภ, 2 우; 广东鼎湖山 [Guangdong, Dinghushan Mt.]; 22 Jul. 1964; 吴思添采 [Wu Sitian leg.]; SYSU・ 1 ○; 广州河南 [Guangzhou, Henan]; 15 Oct. 1992; 广阝氜采 [Kuang Biao leg.]; SYSU • 1 \% ; 广东乳源南岭半山腰保护站 [Guangdong, Ruyuan, Nanling Hillside Reserve Station]; alt. 1000 m; 23 Aug. 2010; 赵爽采 [Zhao Shuang leg.]; SYSU • 1 q; 广东高明杨梅镇 [Guangdong,

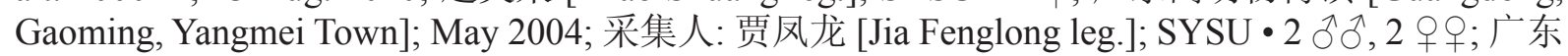
高明杨梅镇 [Guangdong, Gaoming, Yangmei Town]; 23-26 Apr. 2006; 采集人: 贾凤龙 [Jia Fenglong leg.]; SYSU • 1 O , 1 O ; 广东高明杨梅镇 [Guangdong, Gaoming, Yangmei Town]; 20-27 Apr. 2006; 袁采亚采 [Yuan Caiya leg.]; SYSU • 1 O ; 广东高明杨梅镇 [Guangdong, Gaoming, Yangmei Town]; 20-27 Apr. 2006; 胡剑采 [Hu Jian leg.]; SYSU.

\section{Distribution}

Endemic to south China. Known from Fujian. New for Guangdong.

\section{Key to the species of Patrus Aubé occurring in China}

The following key is based on the species of which we have examined material from China. The following 13 species known from China were not included in the key because we were not able to examine any material of these species from China: Patrus metallicus (Régimbart, 1884), P. sculpturatus (Régimbart, 1884), P. chinensis (Régimbart, 1892), P. sublineatus (Régimbart, 1892), P. sulcipennis (Régimbart, 1892), P. fallax (Peschet, 1923), P. mimicus (Ochs, 1936), P. minusculus (Ochs, 1936), 
P. depressiusculus (Ochs, 1940), P. helferi (Ochs, 1940), P. distinguendus (Ochs, 1942), P. klapperichi (Ochs, 1942) and P. jaechi (Mazzoldi, 1998).

1. Labrum semi-circular, about half as long as wide, with anterior margin rounded

- Labrum short and wide, less than $1 / 3$ as long as wide, with anterior margin truncate or slightly convex

2. Epipleural angle of elytra prolonged into a spine (Fig. 11E)

P. annandalei (Ochs, 1925)

- Epipleural angle of elytra not prolonged into a spine

3. Labrum bright yellow, evidently differs from colour of clypeus (Fig. 15A) ………………........... 4

- Labrum brown or black, concolorous with clypeus .................................................................. 5

4. Size larger, long 5.5-6.0 mm ................................... marginepennis angustilimbus (Ochs, 1925)

- Size smaller, long 4.0-4.5 mm ..................................... marginepennis parvilimbus (Ochs, 1925)

5. Posterior margin of elytral glabrous region irregular, trilobate in apical $1 / 2$ at each elytron (Fig. 13AB)

P. haemorrhous (Régimbart, 1891)

- Posterior margin of elytral glabrous region evenly curved towards suture

P. jilanzhui (Mazzoldi, 1998)

6. Pronotum and elytra without yellow or reddish lateral border

- Pronotum and elytra with yellow or reddish lateral border

7. Protarsus in male wider than protibia or at least as wide as protibia; apex of aedeagus needle-shaped; glabrous region in female produced at posterolateral area posteriorly

P. apicalis subapicalis (Ochs, 1930)

- Protarsus in male narrower than protibia; apex of aedeagus regularly narrowed; glabrous region in female not produced at posterolateral area, but forming a clear angle

P. landaisi (Régimbart, 1892)

8. Elytra very smooth, without obvious reticulation or punctation; epipleural angle of elytra prolonged into a spine

- Elytra with obvious punctation; epipleural angle of elytra not prolonged into a spine

9. Lateral pubescence on pronotum strongly expanded inward anteriorly, at least reaching middle of the eye

- Expansion of lateral pubescence on anterior pronotum never reaching middle of the eye, at most reaching outer third of the eye

10. Surface of elytra with dense micro-punctation among the larger punctation (Fig.13F)

- Surface of elytra without obvious micro-punctations among the punctation

11. Dorsal habitus broader, epipleural angle not acute, narrowly rounded

P. melli (Ochs, 1925)

- Dorsal habitus elongate, epipleural angle acute (Fig. 12G), but never prolonged into a spine ...... 12

12. Elytral glabrous region strongly sexually dimorphic: elytral glabrous region lanceolate in posterior $1 / 2$ in male, elongate oval and weakly acuminate posteriorly in female (Fig. 12A-D)

- Elytral glabrous region without evident sexual dimorphism, regularly cordiform 
13. Epipleural angle acute, but never prolonged into a spine P. hainanensis sp. nov.

- Epipleural angle not acute, narrowly rounded

14. Lateral borders on pronotum and elytra testaceous to dark testaceous

P. emmerichi (Falkenström, 1936)

- Lateral borders on pronotum and elytra yellow

15. Elytral glabrous region oval, not acuminate posteriorly

.P. cribratellus cribratellus (Régimbart, 1891)

- Elytral glabrous region cordiform, obviously acuminate posteriorly

P. figuratus (Régimbart, 1892)

16. Lateral pubescence on pronotum not expanded or slightly expanded inwards anteriorly

- Lateral pubescence on pronotum distinctly expanded inwards to about external third of the eye anteriorly

17. Lateral pubescence on pronotum slightly expanded inwards; protarsus of male strongly expanded, almost as long as protibia

- Lateral pubescence on pronotum never expanded inwards anteriorly, only reaching external edge of the eye; protarsus of male obviously shorter than tibiae

18. Aedeagus terminating with a reverse heart shape

P. chalceus (Ochs, 1936)

- Aedeagus not terminating with a reverse heart shape, rounded apically

P. schillhammeri (Mazzoldi, 1998)

19. Truncature of elytra straight

P. severini (Régimbart, 1892)

- Truncature of elytra slightly oblique P. assequens (Ochs, 1936)

20. Protarsus in male about as long as protibia

- Protarsus in male clearly longer than protibia

21. Elytral glabrous region regularly oval in both sexes, much wider posteriorly in female; median lobe broader apically

.P. wui (Ochs, 1932)

- Elytral glabrous region regularly oval in male, with a postero-lateral expansions on each side in female (Fig. 5A-B); median lobe narrower apically

P. shangchuanensis sp. nov.

22. Elytral glabrous region with minor sexual dimorphism, regularly oval in both sexes, wider posteriorly in female P. jiangxiensis sp. nov.

- Elytral glabrous region on elytra strongly sexually dimorphic: regularly oval in male, with a posterolateral expansions on each side in female (Mazzoldi, 1998: figs 1, 4a) ...P. wangi (Mazzoldi, 1998)

\section{Discussion}

Since the 1950s, many new species of true aquatic beetles, such as Dytiscidae and Hydrophilidae, have been described from the Oriental Region (e.g., Schönmann 1995; Hendrich \& Yang 1999; Komarek 2013; Balke et al. 2017; Jia et al. 2017). However, Gyrinidae have been poorly studied in the Oriental Region except for some contributions to the Chinese (Mazzoldi 1998) and Indian (Vazirani 1984; Miller et al. 2008) faunas. Although we can assume that Gyrinidae are fairly well known at generic level, it is quite believable that there is still an enormous potential for more new species to be described in this area. Our discovery of three new species of Patrus and newly recorded species for China, extends the known range of Gyrinidae in China. 
LIANG Z. et al., Three new species of Patrus with additional records of Gyrinidae from China

Patrus is a typical Oriental group and all species of the genus are distributed in the Oriental Region except for one unusual species occurring in central Africa. In China specifically, all species are only known from south of the Qinling-Huaihe Line, which is typically considered the northern border of the Oriental region in China (Cox 2001). The species diversity of the genus in China is rather high (37 species known to date), especially in Fujian, Guangdong, Guangxi and Yunnan Provinces, probably because of the warmer climate condition. In contrast to the Indian and Indochinese peninsular fauna, 21 Chinese species were only known from China, some of which seem to be very local and are likely endemic (e.g., P. emmerichi, P. chinensis). Habitats of Patrus show that many species live on the surface of running water, some living on the surface of standing water or small ponds by rivers, covered with grass (e.g., P. productus). Based on our experiences during field collection, it seems that species occurring in standing water tend to have larger ranges than species in running waters. This assumption needs to be tested in further studies.

Yunnan is an interesting area for the Chinese fauna of Patrus, where abundant species occur. Yunnan is a border province neighbouring several countries of the Indochinese Peninsula without obvious geographical barriers, making its Patrus fauna more similar to that of the Indochinese Peninsula than to other areas of China. Of the seven species of Patrus known from Yunnan, six are shared with the Indochinese Peninsula fauna, while none is shared with other areas in China. Unfortunately, the fauna of Patrus of the Indochinese Peninsula is currently even less known when compared to the Chinese fauna. Hence, any future revisionary work on Chinese Patrus fauna should include as many species as possible occurring in adjacent countries in the Indochinese Peninsula.

\section{Acknowledgements}

We are very grateful to Dr Grey Gustafson and an anonymous reviewer for their professional opinions on revising this manuscript. We are indebted to Dr Chen Jun and Dr Kui-yang Zhang, both in Chinese Academy of Sciences, Institute of Zoology, Beijing, China, for their kind help in examining specimens. We are grateful to Mr Antoine Mantilleri from the Muséum national d'histoire naturelle, Paris, for taking the photographs of some type material deposited in MNHN. We are also indebted to Mr Zuqi Mai for helping the first author in examining the material. This study was supported by the National Natural Science Foundation of China (grant no. 31772494).

\section{References}

Aubé C. 1836-1838. Iconographie et Histoire Naturelle des Coléoptères d'Europe. Tome Cinquième. Hydrocanthares. Méquignon-Marvis, Paris.

Balke M., Bergsten J., Wang L.-J. \& Hendrich L. 2017. A new genus and two new species of Southeast Asian Bidessini as well as new synonyms for Oceanian species (Coleoptera, Dytiscidae). ZooKeys 647: 137-151. https://doi.org/10.3897/zookeys.647.11231

Blanchard E. 1843. Insectes. In: Hombron J.B. \& Jacquinot H. (eds) Atlas d'Histoire Naturelle Zoologie, par MM. Hombron et Jacquinot, chirurgiens de l'expédition. Gide, Paris.

Cheo M.T. 1934. The Gyrinidae of China. Peking Natural History Bulletin 8 (3): 205-239.

Cox B. (2001) The biogeographic regions reconsidered. Journal of Biogeography 28 (4): 511-523. https://doi.org/10.1046/j.1365-2699.2001.00566.x

de Motschulsky V. 1866. Catalogue des insectes reçus du Japon. Bulletin de la Société impériale des Naturalistes de Moscou 39: 163-200.

Deyrolle H. \& Fairmaire L. 1878. Descriptions de coléoptères recueillis par M. l'abbé David dans la Chine centrale. Annales de la Société entomologique de France 8: 87-140. 
Fabricius J.C. 1775. Systema Entomologiae, Sistens Insectorum Classes, Ordines, Genera, Species, Adiectis Synonymis, Locis, Descriptionibus, Observationibus. Libraria Kortii, Flensburgi et Lipsiae.

Fabricius J.C. 1798. Entomologia Systematica. apud Proft et Storch, Hafniae.

Fabricius J.C. 1801. Systema Eleutheratorum secundum ordines, genera, species; adiectis synonymis, locis, observationibus, descriptionibus. Tomus I. Bibliopolii Academici Novi, Kiliae.

Falkenström G. 1936. Halipliden, Dytisciden und Gyriniden aus West- und Central-China (Coleoptera). Lingnan Science Journal 15 (1-2): 79-99, 225-247.

Fery H. \& Hájek J. 2016. Nomenclatural notes on some Palaearctic Gyrinidae (Coleoptera). Acta Entomologica Musei Nationalis Pragae 56 (2): 645-663.

Gustafson G.T. \& Miller K.B. 2017. Systematics and evolution of the whirligig beetle tribe Dineutini (Coleoptera: Gyrinidae: Gyrininae). Zoological Journal of the Linnean Society 181 (1): 118-150. https://doi.org/10.1093/zoolinnean/zlw014

Hájek J. \& Fery H. 2017. Family Gyrinidae Latreille, 1810. In: Löbl I. \& Löbl D. (eds), Catalogue of Palaearctic Coleoptera. Volume 1. Revised and Updated Edition. Archostemata - MyxophagaAdephaga: 22-29. Leiden, Brill.

Hájek J. \& Fery H. 2019. Catalogue of Palearctic Gyrinidae (Coleoptera). Internet version. 1-14. Available from http://waterbeetles.eu/documents/PAL_CAT_Gyrinidae_2019.pdf [accessed 1 Jan. 2019]

Hatch M. 1925. The phylogeny and phylogenetic tendencies of Gyrinidae. Paper of the Michigan Academy of Science, Arts and Letters 5: 429-467.

Hendrich L. \& Yang C.M. 1999. A contribution to the knowledge of the water beetle fauna of Pulau Tioman, Peninsular Malaysia (Coleoptera: Noteridae, Dytiscidae, Hydrophilidae, Hydraenidae, Scirtidae, Limnichidae). The Raffles Bulletin of Zoology Supplement No. 6: 253-262.

Holmen M. 1987. The aquatic Adephaga (Coleoptera) of Fennoscandia and Denmark, I. Gyrinidae, Haliplidae, Hygrobiidae and Noteridae. Fauna Entomologica Scandinavica 20: 1-168.

Hope F.W. 1842. Observations on the Coleoptera of Port Essington, in Australia, with descriptions of the following new species. Journal of Proceedings of the Entomological Society of London 1841: 43-50.

Jia F.-L., Lin R.-C., Chan E., Skale A. \& Fikáček M. 2017. Two new species of Coelostoma Brullé, 1835 from China and additional faunistic records of the genus from the Oriental Region (Coleoptera: Hydrophilidae: Sphaeridiinae: Coelostomatini). Zootaxa 4232 (1): 113-122.

https://doi.org/10.11646/zootaxa.4232.1.8

Komarek A. 2013. A revision of Anacaena Thomson, 1859 X. Laos, Malaysia, Myanmar, Thailand, and Vietnam (Coleoptera: Hydrophilidae). Entomologica Basiliensia et Collectionis Frey 34: 137-177.

Macleay W.S. 1825. Annulosa Javanica, or an Attempt to Illustrate the Natural Affinities and Analogies of the Insects Collected in Java by Thomas Horsfield, M.D. F.L. \& G.S. and Deposited by Him in the Huseum of the Honourable East-India Company. Number I. Kingsbury, Parbury \& Allen, London.

MacLeay W.S. 1871. Notes on a collection of insects from Gayndah. Transactions of the Entomological Society of New South Wales 2 (2): 79-205.

Marsham T. 1802. Entomologia Britannica. Vol. 1. Coleoptera. White, Londini.

Mazzoldi P. 1995. Gyrinidae: Catalogue of Chinese Gyrinidae (Coleoptera). In: Jäch M.A. \& Ji L. (eds) Water beetles of China: 155-172. Zoologisch-Botanische Gesellschaft in Österreich and Wiener Coleopterologenverein, Vienna. 
Mazzoldi P. 1998. Gyrinidae: New species of Orectochilus Dejean, 1833 subgenus Patrus Aubé, 1838 (Coleoptera). In: Jäch M.A. \& Ji L. (eds) Water Beetles of China: 137-146. Zoologisch-Botanische Gesellschaft in Österreichs and Wiener Coleopterologenverein, Vienna.

Mazzoldi P. 2003. Family Gyrinidae Latreille, 1810. In: Löbl I. \& Smetana A. (eds) Catalogue of Palaearctic Coleoptera. Volume 1. Archostemata - Myxophaga-Adephaga: 26-30. Apollo Books, Stenstrup.

Miller K.B. \& Bergsten J. 2012. Phylogeny and classification of whirligig beetles (Coleoptera: Gyrinidae): relaxed-clock model outperforms parsimony and time-free Bayesian analyses. Systematic Entomology 37 (4): 706-746. https://doi.org/10.1111/j.1365-3113.2012.00640.x

Miller K.B. \& Mazzoldi P., Wheeler Q.D. 2008. An unusual new species of Gyrinidae (Coleoptera), Orectochilus orbisonorum n. sp., from India. Zootaxa 1712: 65-68.

https://doi.org/10.11646/zootaxa.1712.1.4

Modeer A. 1776. Anmärkningar angående slägtet Gyrinus [Notes on the genus Gyrinus]. Physiographiska Sällskapets Handlingar 1 (3): 155-162.

Montrouzier P. 1860. Essai sur la faune entomologique de la Nouvelle-Calédonie (Balade) et des îles des Pins, Art, Lifu etc. Annales de la Société entomologique de France (3) 8: 229-308.

Ochs G. 1924. Über neue und interessante Gyriniden aus dem British Museum in London. Entomologische Blätter 20: 228-244.

Ochs G. 1925. Descriptions of new Asiatic Gyrinidae. Records of the Indian Museum 27: 193-204.

Ochs G. 1926. Die Dineutini. 2. Tribus der Unterfamilien Enhydrinae Fam. Gyrinidae, (Col). Entomologische Zeitschrift 40: 61-197.

Ochs G. 1927. Ueber sibirische Gyriniden. Entomologische Zeitschrift 41 (2): 46-49.

Ochs G. 1928. Über die Gyriniden Borneo‘s. Entomologische Blätter 24: 41-45, 78-85, 93-103.

Ochs G. 1929. The present status of knowledge about Chinese Gyrinidae. Lignan Science Journal 7: 715-720.

Ochs G. 1930. Catalogue of Indian insects. Part 19. -Gyrinoidea. Government of India Central Publications Branch, New Delhi.

Ochs G. 1932. Note on species of Gyrinidae from China. Peking Natural History Bulletin 6: 57-58.

Ochs G. 1936. Ein neuer Beitrag zur Kenntnis der Gyriniden-Fauna Chinas unter Berücksichtigung einiger verwandter Arten aus Hinter-Indien. Festschrift für Prof. Dr. Embrik Strand 1: 601-613.

Ochs G. 1942. Über die von Herrn J. Klapperich in China 1937-38 gesammelten Gyriniden. Mitteilungen der Münchner Entomologischen Gesellschaft 32: 201-207.

Pascoe F.P. 1877. Descriptions of new genera and species of New-Zealand Coleoptera. - Part IV. Journal of Natural History 19 (110): 140-147.

Peschet R. 1923. Faune entomologique de l'Indochine. Gyrinidae. Opuscules de l'Institut Scientifique de l'Indochine 1 (6): 121-136.

Peschet R. 1925. Description d'un Orectochilus nouveau du Tonkin [Col. Gyrinidae]. Bulletin de la Société entomologique de France 30 (15): 253-254.

Régimbart M. 1882. Essai monographique de la famille des Gyrinidae:1er partie. Annales de la Société entomologique de France 6 (2): 379-458. 
Régimbart M. 1883. Essai monographique de la famille des Gyrinidae:2 $2^{\mathrm{e}}$ partie. Annales de la Société entomologique de France 6 (3): 121-190.

Régimbart M. 1884. Essai monographique de la famille des Gyrinidae:3e partie. Annales de la Société entomologique de France 6 (3): 381-482.

Régimbart M. 1886. Essai monographique de la famille des Gyrinidae: $1^{\text {er }}$ supplément. Annales de la Société entomologique de France 6 (6): 247-272.

Régimbart M. 1888. Viaggio di Leonardo Fea in Birmania e regioni vicine. Annali del Museo Civico di Storia Naturale di Genova 26: 609-623.

Régimbart M. 1891.Gyrinidae de Birmanie. In: Doria G. \& Gestro E.R. (eds) Storia naturale di Genova, Serie 2a, Vol. X: 547-554. Tipografia Del R. Istituto Sordo-Muti, Genova.

Régimbart M. 1892. Essai monographique de la famille des Gyrinidae: $2^{\mathrm{e}}$ supplément. Annales de la Société entomologique de France (60): 663-752.

Régimbart M. 1902. Coleoptera. Fam. Gyrinidae. In: Wytsman I.P. (ed.) Genera Insectorum. V. Verteneui and L. Desmet, Brussels, Belgium.

Régimbart M. 1907. Essai monographique de la famille des Gyrinidae: $3^{\mathrm{e}}$ supplément. Annales de la Société entomologique de France (76): 137-245.

Ryndevich S.K., Foster G.N., Bilton D.T., Aquilina R., Turner C.R., Shaverdo H. \& Prokin A.A. 2014. Additions to the Belarusian fauna of water beetles. Latissimus (35): 32-42.

Satô M. 1985. New aquatic beetles from Japan. Transactions of the Shikoku Entomological Society 17: $51-55$.

Schönmann H. 1995. Revision der Gattung Pelthydrus Orchymont 2. Teil: Pelthydrus s.str. (Coleoptera: Hydrophilidae). Koleopterologische Rundschau 65 105-144.

Sharp D. 1873. The water beetles of Japan. The Transactions of the Entomological Society of London: 45-67.

Short A.E.Z. 2018. Systematics of aquatic beetles (Coleoptera): current state and future directions. Systematic Entomology 43 (1): 1-18. https://doi.org/10.1111/syen.12270

Suffrian E. 1842. Fragmente zurgenaueren Kenntniss deutscher Käfer. 3. Gyrinus Geoffr. Entomologische Zeitung 3: 219-237.

Takizawa M. 1931. The Gyrinidae of Japan. Insecta matsumurana 6 (1-2): 13-21.

Uyttenboogaart D.L. 1915. Description d'une nouvelle espece de Dineutes (Fam. Gyrinidae) de l'ile de Formosa. Zoologische Mededelingen 1: 140.

Wu C.F. 1932. Aquatic insects of China. Article I. Catalogue of Chinese Gyrinidae. Peking Natural History Bulletin 6 III. 63-73.

Zaitzev F.A. 1908. Berichtigungen und Zusätze zu den Haliplidae, Dytiscidae und Gyrinidae in den neuesten Katalogen der Coleoptera. Russkoe Entomologicheskoe Obozrenie 7 (1907): 114-124.

Manuscript received: 30 October 2020

Manuscript accepted: 27 July 2021

Published on: 2 September 2021

Topic editor: Nesrine Akkari 
Section editor: Max Barclay

Desk editor: Eva-Maria Levermann

Printed versions of all papers are also deposited in the libraries of the institutes that are members of the EJT consortium: Muséum national d'histoire naturelle, Paris, France; Meise Botanic Garden, Belgium; Royal Museum for Central Africa, Tervuren, Belgium; Royal Belgian Institute of Natural Sciences, Brussels, Belgium; Natural History Museum of Denmark, Copenhagen, Denmark; Naturalis Biodiversity Center, Leiden, the Netherlands; Museo Nacional de Ciencias Naturales-CSIC, Madrid, Spain; Real Jardín Botánico de Madrid CSIC, Spain; Zoological Research Museum Alexander Koenig, Bonn, Germany; National Museum, Prague, Czech Republic. 